Prepared in cooperation with Jefferson County and the Washington State Department of Ecology

\title{
Hydrogeologic Framework, Groundwater Movement, and Water Budget in the Chimacum Creek Basin and Vicinity, Jefferson County, Washington
}

Scientific Investigations Report 2011-5129 



\section{Hydrogeologic Framework, Groundwater Movement, and Water Budget in the Chimacum Creek Basin and Vicinity, Jefferson County, Washington}

By Joseph L. Jones, Wendy B. Welch, Lonna M. Frans, and Theresa D. Olsen

Prepared in cooperation with Jefferson County and the Washington State

Department of Ecology

Scientific-Investigations Report 2011-5129 


\title{
U.S. Department of the Interior \\ KEN SALAZAR, Secretary \\ U.S. Geological Survey \\ Marcia K. McNutt, Director
}

\author{
U.S. Geological Survey, Reston, Virginia: 2011
}

For more information on the USGS - the Federal source for science about the Earth, its natural and living resources, natural hazards, and the environment, visit http://www.usgs.gov or call 1-888-ASK-USGS.

For an overview of USGS information products, including maps, imagery, and publications, visit http://www.usgs.gov/pubprod

To order this and other USGS information products, visit http://store.usgs.gov

Any use of trade, product, or firm names is for descriptive purposes only and does not imply endorsement by the U.S. Government.

Although this report is in the public domain, permission must be secured from the individual copyright owners to reproduce any copyrighted materials contained within this report.

Suggested citation:

Jones, J.L., Welch, W.B., Frans, L.M., and Olsen, T.D., 2011, Hydrogeologic framework, groundwater movement, and water budget in the Chimacum Creek basin and vicinity, Jefferson County, Washington: U.S. Geological Survey Scientific Investigations Report 2011-5129, 28 p. 


\section{Contents}

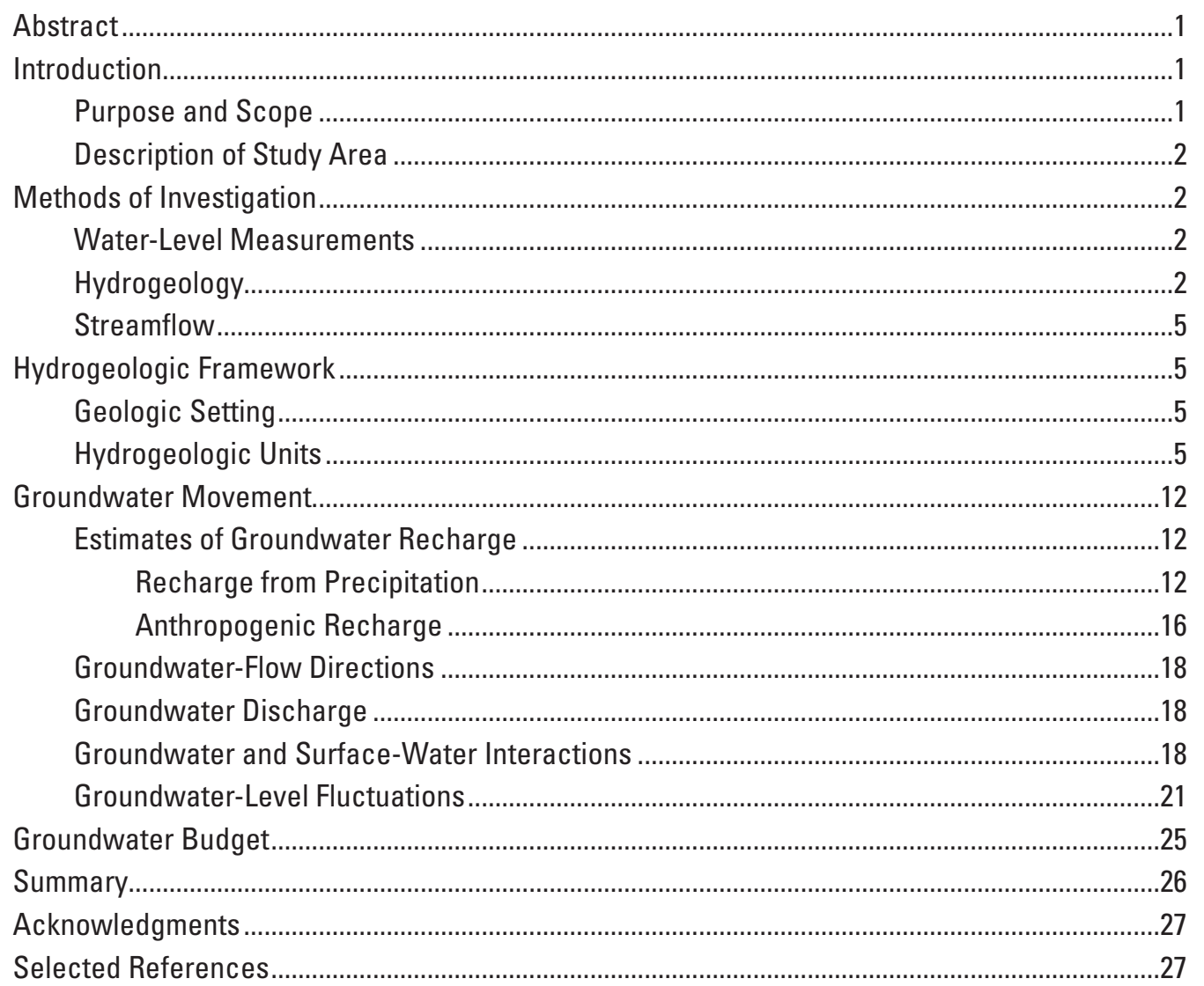




\section{Plate}

Plate 1. Map and hydrogeologic sections showing surficial hydrogeology, hydrogeologic units, and locations of selected wells and streamflow measurements sites, Chimacum Creek Basin and Vicinity, Jefferson County, Washington.

\section{Figures}

Figure 1. Map showing location of Chimacum Creek basin and vicinity, Washington

Figure 2. Map showing extent and thickness of Upper Confining unit in Chimacum Creek basin and vicinity, Washington

Figure 3. Map showing extent and thickness of Upper Aquifer unit in Chimacum Creek basin and vicinity, Washington

Figure 4. Map showing extent and thickness of Middle Confining unit in Chimacum Creek basin and vicinity, Washington

Figure 5. Map showing extent and thickness of Lower Aquifer unit in Chimacum Creek basin and vicinity, Washington

Figure 6. Map showing extent and thickness Lower Confining unit (LC) of in Chimacum Creek basin and vicinity, Washington

Figure 7. Map showing average annual precipitation in the Chimacum Creek basin and vicinity, Washington, water years 1995-2009

Figure 8. Graph showing precipitation-recharge relations used in this study, Chimacum Creek basin, Washington

Figure 9. Map showing average annual recharge from precipitation in the Chimacum Creek basin and vicinity, Washington, 1995-2009

Figure 10. Map showing Areas of groundwater recharge from public-supply, domestic and agricultural sources, Chimacum Creek basin and vicinity, Washington, water years 1995-2009

Figure 11. Map showing estimated water table elevation, water-level contours, and approximate directions of groundwater flow in the Lower Aquifer and Lower Confining units, Chimacum Creek basin and vicinity, Washington

Figure 12. Map showing synoptic streamflow measurements and gain/loss amounts, Chimacum Creek basin and vicinity, Washington, July 10, 2007

Figure 13. Map showing locations of monitoring wells, Chimacum Creek basin and vicinity, Washington

Figure 14. Graphs showing water table elevations at monitoring wells in the Chimacum Creek basin and vicinity, Washington, for parts of 2002, 2003, 2008, and 2009

Figure 15. Graph showing publicly- and self-supplied water for domestic use, and associated return flows for the Chimacum Creek basin and vicinity, Washington 


\section{Tables}

Table 1. Hydrogeologic units defined in this study and correlation with hydrogeologic units defined by previous investigations

Table 2. Water use by residents within the Jefferson County Public Utility District \# 1 (public-supply use), and by residents outside the public-supply area (self-supplied use); and the resultant recharge of groundwater by return flow from each class of user, during each year of the recorded period 1994-2009

Table 3. Monthly mean indoor and outdoor water use rates for self-supplied domestic water use in the Chimacum Creek basin and vicinity, Washington, water years 1995-2005

Table 4. Synoptic stream discharges in Chimacum Creek, Washington, measured on June 26, 2002, October 22, 2002, and July 10, 2007

Table 5. Physical and hydrologic data for monitoring wells in the Chimacum Creek basin, Washington

Table 6. Total estimable groundwater inflows and outflows, and residual, for the Chimacum Creek basin, Washington....

\section{Conversion Factors and Datums}

\section{Conversion Factors}

\begin{tabular}{lcl}
\hline \multicolumn{1}{c}{ Multiply } & By & \multicolumn{1}{c}{ To obtain } \\
\hline acre-foot (acre-ft) & 1,233 & cubic meter \\
acre-foot per day (acre-ft/d) & 0.01427 & cubic meter per second \\
acre-foot per year (acre-ft/yr) & 1,233 & cubic meter per year \\
cubic foot per second (ft $\left.{ }^{3} / \mathrm{s}\right)$ & 0.02832 & cubic meter per second \\
inch (in.) & 2.54 & centimeter \\
inch (in.) & 25.4 & millimeter \\
inch per year (in./yr) & 25.4 & millimeter per year \\
foot (ft) & 0.3048 & meter \\
mile (mi) & 1.609 & kilometer \\
gallon (gal) & 3.785 & liter \\
gallon per day (gal/d) & 0.003785 & cubic meter per day \\
square mile (mi ${ }^{2}$ ) & 2.590 & square kilometer \\
\hline
\end{tabular}

\section{Datums}

Vertical coordinate information was referenced to the National Geodetic Vertical Datum of 1929 (NGVD 29.

Horizontal coordinate information was referenced to the North American Datum of 1983 (NAD 83).

Altitude, as used in this report, refers to distance above or below sea level. 


\section{Well-Numbering System}

Wells in Washington State are assigned a local well number that identifies each well based on its location within a township $(T)$, range $(R)$, section, and 40-acre tract. For example, well 29N/01W-35J01 refers to township (T. $29 \mathrm{~N}$ ) and the range (R. $01 \mathrm{~W}$ ) north of the Willamette Base Line and west of the Willamette Meridian. The first number following the hyphen indicates the section (35) within the township, and the letter $(\mathrm{J})$ following the section number indicates the 40 -acre subdivision of the section. The final two-digit number (01) uniquely distinguishes

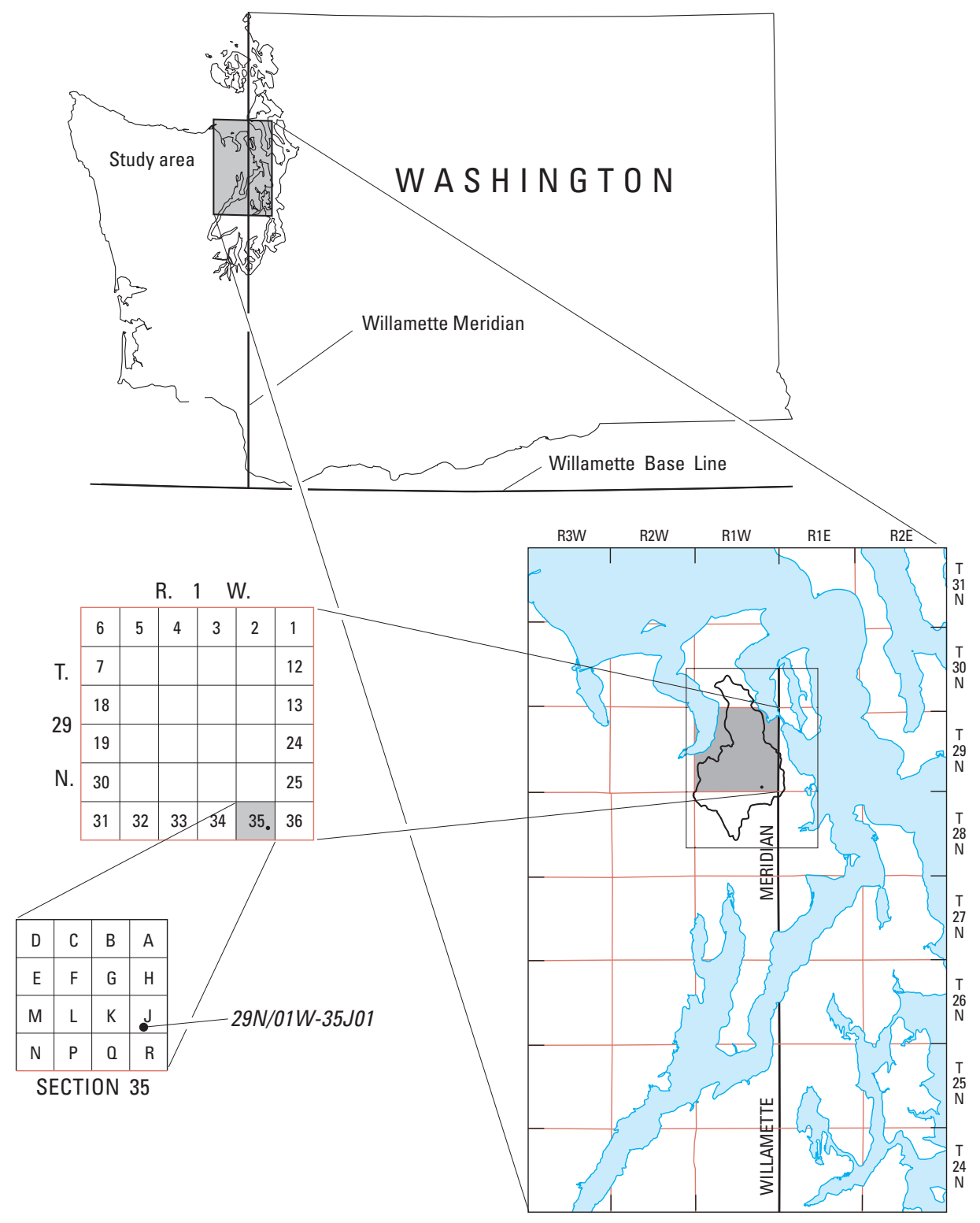




\title{
Hydrogeologic Framework, Groundwater Movement, and Water Budget in the Chimacum Creek Basin and Vicinity, Jefferson County, Washington
}

\author{
By Joseph L. Jones, Wendy B. Welch, Lonna M. Frans, and Theresa D. Olsen
}

\section{Abstract}

This report presents information used to characterize the groundwater flow system in the Chimacum Creek basin. It includes descriptions of the geology and hydrogeologic framework; groundwater recharge and discharge; groundwater levels and flow directions; seasonal fluctuations in groundwater level; interactions between aquifers and the surface-water system; and a groundwater budget. The study area covers 124 square miles in northeastern Jefferson County, Washington, and includes the Chimacum Creek basin, which drains an area of about 37 square miles. The area is underlain by a north-thickening sequence of unconsolidated glacial and interglacial deposits that overlie sedimentary and igneous bedrock units that crop out along the margins and western interior of the study area. Six hydrogeologic units consisting of unconsolidated aquifers and confining units, along with an underlying bedrock unit, were identified. A surficial hydrogeologic map was developed and used with well information from 187 drillers' logs to construct 4 hydrogeologic sections, and maps showing the extent and thickness of the units. Natural recharge was estimated using precipitation-recharge relation regression equations developed for western Washington, and estimates were calculated for return flow from data on domestic indoor and outdoor use and irrigated agriculture. Results from synoptic streamflow measurements and water table elevations determined from monthly measurements at monitoring wells are presented and compared with those from a study conducted during 2002-03. A water budget was calculated comprising long-term average recharge, domestic public-supply withdrawals and return flow, self-supplied domestic withdrawals and return flow, and irrigated agricultural withdrawals and return flow.

\section{Introduction}

Projected increases in population and development in northeastern Jefferson County, Washington, are expected to lead to increased groundwater withdrawals in the Chimacum Creek basin. In addition, land use and climate change could reduce groundwater recharge in the basin, thereby reducing groundwater levels and discharge from the groundwater system to Chimacum Creek. Groundwater discharge to the creek, also referred to as baseflow, is critical for maintaining ecological health in the creek throughout the year, and it is especially important during the summer and early autumn, when it supplies most, if not all, streamflow. Chimacum Creek provides habitat for salmonids, including species listed under the Endangered Species Act (ESA), such as summer-run chum salmon (threatened), coho salmon (species of concern), and steelhead (proposed for listing as threatened in March 2006) (National Oceanic and Atmospheric Administration, 2006). Decision makers and water-resources managers need quantitative tools to assess the impact of different watermanagement options so that they can plan for future growth and development in ways that minimize adverse impacts on Chimacum Creek.

In April 2007, the U.S. Geological Survey (USGS) Washington Water Science Center, in cooperation with Jefferson County and the Washington State Department of Ecology, began a study to understand the potential impact of different patterns of growth and water-management strategies on the groundwater and surface-water resources of the Chimacum Creek basin. This study is based on information from previous studies as well as newly collected data.

\section{Purpose and Scope}

This report presents information used to characterize the groundwater flow system in the Chimacum Creek basin and vicinity; describes the geology and hydrogeologic framework of the area; groundwater recharge and discharge; groundwater levels and flow directions; seasonal fluctuations in groundwater level; interactions between aquifers and the surface-water system; and a groundwater budget. A second phase of this study will integrate this and other information into a numerical groundwater-flow model to evaluate potential future impacts of growth and of water-management strategies on water resources in the Chimacum Creek basin. 


\section{Description of Study Area}

The study area covers about $124 \mathrm{mi}^{2}$ on the Olympic Peninsula in northeastern Jefferson County, Washington (fig. 1). The Chimacum Creek basin drains an area of about $37 \mathrm{mi}^{2}$ and consists of Chimacum Creek and its tributary East Fork Chimacum Creek. These creeks converge near the town of Chimacum and discharge to Port Townsend Bay near the town of Irondale. The topography of the study area consists of narrow, regularly spaced parallel ridges and grooves that are characteristic of a fluted glaciated surface; they are oriented in a north-south direction (Ritter, 1978). This surface has been incised locally by fluvial and postglacial erosion, producing steep sides and hummocky bottoms for the valley. Thick accumulations of peat occur along the axis of larger valleys and provide rich soils for agricultural use. Bedrock outcrops generally are low and exhibit glacial-scouring features. The study area is underlain by a north-thickening sequence of unconsolidated glacial and interglacial deposits. Sedimentary and igneous bedrock units underlie the unconsolidated deposits and crop out along the margins and the western interior of the study area.

The study area has a temperate marine climate with warm, dry summers, and cool, wet winters. Chimacum Creek basin lies within the rain shadow of the Olympic Mountains, and its annual average precipitation during (1971-2000) at the community of Center (fig. 1) is $29.3 \mathrm{in} / \mathrm{yr}$ (National Oceanic and Atmospheric Administration, 2007). In 1996, the population of the Chimacum Creek basin was 5,675, and it is projected to increase by almost 30 percent by 2016 (Parametrix and others, 2000). The highest population density in the basin occurs near the mouth of Chimacum Creek, in the general area of Irondale, Port Hadlock, and Chimacum (fig. 1).

\section{Methods of Investigation}

Methods used to compile and analyze information for characterizing the groundwater flow system in the study area are described in this section. Methods used to determine groundwater movement (p. 12) and to estimate water-budget components (p. 25) are described in later sections of this report.

\section{Water-Level Measurements}

Water levels were measured on a monthly basis during January 2008-May 2009 in eight of the nine wells previously monitored (March 2002-July 2003) by Simonds and others (2004). Monthly water-level measurements were discontinued in one well $(28 \mathrm{~N} / 01 \mathrm{~W}-13 \mathrm{M} 01)$ due to lack of owner permission. Latitude and longitude locations were determined for each well using a Global Positioning System (GPS) receiver with a horizontal accuracy of $1 / 2$ second of arc (about $50 \mathrm{ft}$ ). Light Detection and Ranging (LiDAR) data were obtained through the Puget Sound LiDAR Consortium (available at http://pugetsoundlidar.ess.washington.edu/), and were used to determine the elevation of land surface at each well, and for the computation of water-level elevations. Vertical accuracy of the LiDAR data was typically $\pm 1 \mathrm{ft}$. Water level, reported as depth to water below land surface, was measured using a graduated steel tape with a stated accuracy of $0.01 \mathrm{ft}$. All water-level measurements were made by personnel from Jefferson County Public Utility District \#1 (PUD \#1) in accordance with standard techniques of the USGS (Drost, 2005). Water-level elevations were determined by subtracting the measured depth to water below land surface from the LiDAR-derived land-surface elevation at the well. Monthly water-level data were entered into the USGS National Water Information System (NWIS) database.

\section{Hydrogeology}

The hydrogeologic units in the Chimacum Creek basin and vicinity were defined using previously published geologic maps, well records with drillers' logs (available from the Washington State Department of Ecology), and previous investigations by Simonds and others (2004), Pacific Groundwater Group (2005), and Golder Associates (2008). The surficial hydrogeologic map for the study area and associated hydrogeologic sections (pl. 1) as developed from the surficial hydrogeologic map and geologic sections prepared by Simonds and others (2004, pl. 1). Fifteen hydrogeologic units delineated by Simonds and others (2004) were grouped into six hydrogeologic units consisting of unconsolidated aquifers and confining units, along with an underlying bedrock unit based on similarities in lithology (grain size and sorting), hydrologic characteristics, and relative stratigraphic position (table 1). The surficial distribution of these six hydrogeologic units (pl. 1) was based on the relation between geologic and hydrogeologic units established by Simonds and others (2004, pl. 1). 


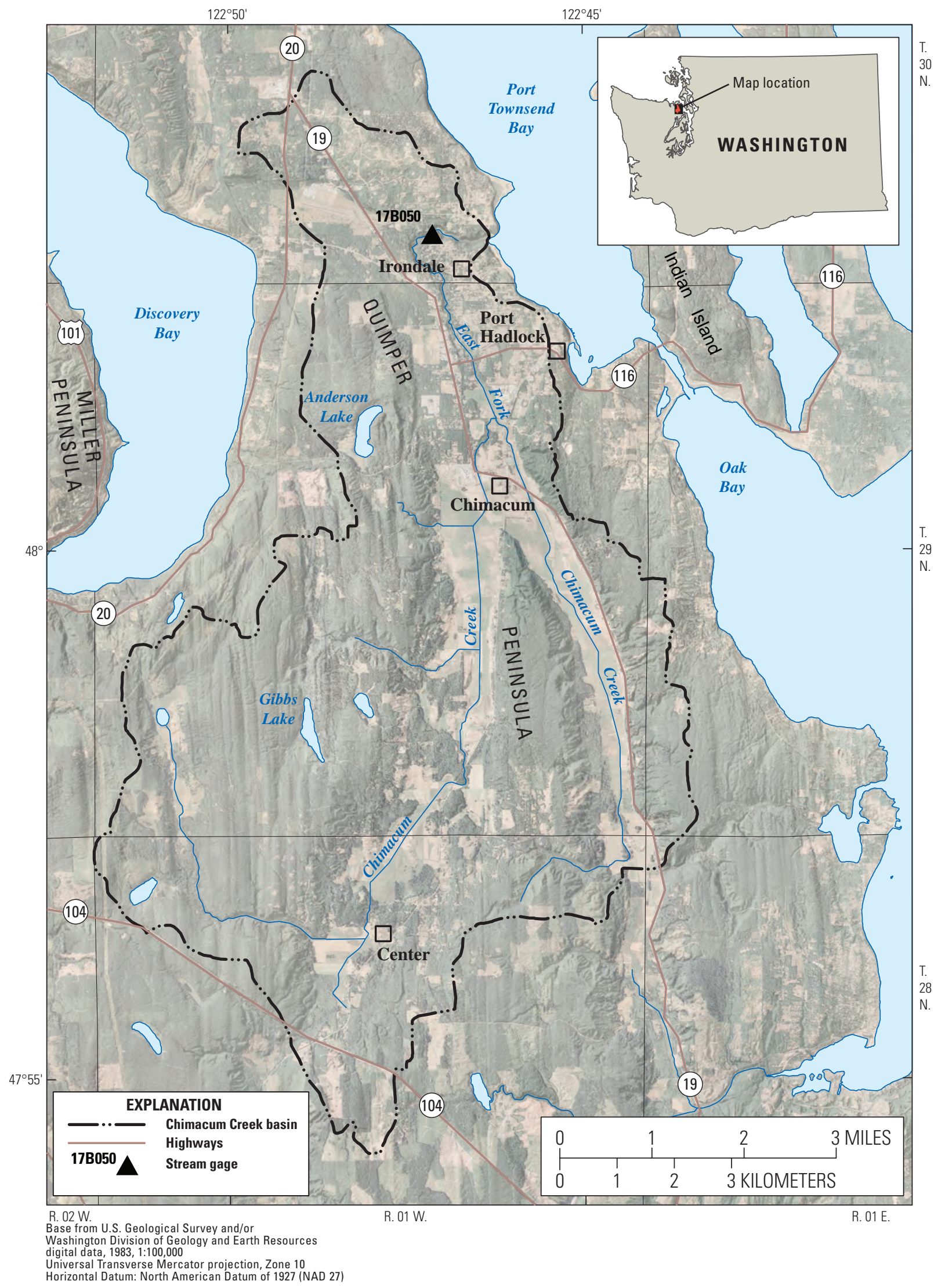

Figure 1. Location of Chimacum Creek basin and vicinity, Washington. 
Table 1. Hydrogeologic units defined in this study and correlation with hydrogeologic units defined by previous investigations.

\begin{tabular}{|c|c|c|c|c|}
\hline Period & Epoch & $\begin{array}{l}\text { Hydrogeologic units } \\
\text { defined in this study }\end{array}$ & Lithology & $\begin{array}{l}\text { Hydrogeologic units } \\
\text { (Simonds and } \\
\text { others, 2004) }\end{array}$ \\
\hline \multirow{5}{*}{ 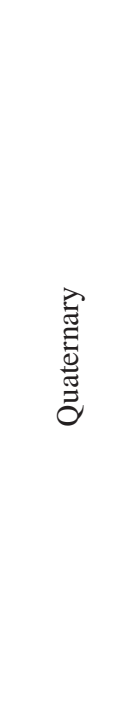 } & $\begin{array}{l}\text { Holocene } \\
\text { and } \\
\text { Pleistocene }\end{array}$ & $\begin{array}{l}\text { UC - Upper Confining Unit } \\
\text { Alluvial and Recessional } \\
\text { Outwash Deposits }\end{array}$ & $\begin{array}{l}\text { Clay, silt, fine grained sand, } \\
\text { organic rich soil, and peat }\end{array}$ & $\begin{array}{l}\text { Qa (fine) } \\
\text { Qa (peat) } \\
\text { Qvr (fine) }\end{array}$ \\
\hline & \multirow{4}{*}{ 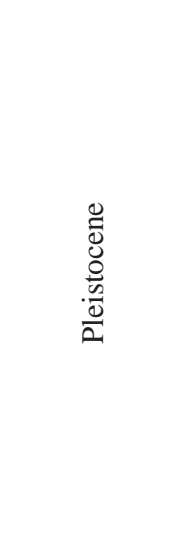 } & $\begin{array}{l}\text { UA - Upper Aquifer } \\
\text { Recessional Outwash and Till }\end{array}$ & Sand, gravel, silt, and clay & $\begin{array}{l}\text { Qvr (coarse) } \\
\text { Qvt (coarse) }\end{array}$ \\
\hline & & $\begin{array}{l}\text { MC - Middle Confining Unit } \\
\text { Recessional Outwash, Till, and } \\
\text { Advance Outwash Deposits }\end{array}$ & $\begin{array}{l}\text { Unsorted and compacted clay, } \\
\text { sand, and gravel; silt and clay }\end{array}$ & $\begin{array}{l}\text { Qvr (fine) } \\
\text { Qvt (fine) } \\
\text { Qva (fine) } \\
\text { Qva (peat) }\end{array}$ \\
\hline & & $\begin{array}{l}\text { LA - Lower Aquifer } \\
\text { Till, and Advance Outwash } \\
\text { Deposits }\end{array}$ & Sand, gravel, silt and clay & $\begin{array}{l}\text { Qvt (coarse) } \\
\text { Qva (coarse) }\end{array}$ \\
\hline & & $\begin{array}{l}\text { LC - Lower Confining Unit } \\
\text { Undifferentiated glacial and } \\
\text { Inter-glacial Deposits }\end{array}$ & $\begin{array}{l}\text { Unsorted and compacted clay, } \\
\text { sand, and gravel; silt and clay; } \\
\text { lenses of sand and gravel }\end{array}$ & $\begin{array}{l}\text { Qgo (fine) } \\
\text { Qgo (coarse) }\end{array}$ \\
\hline Tertiary & $\begin{array}{l}\text { Oligocene to } \\
\text { Eocene }\end{array}$ & $\begin{array}{l}\text { OE - Bedrock } \\
\text { Sedimentary and Igneous Rocks }\end{array}$ & $\begin{array}{l}\text { Sandstone, siltstone, } \\
\text { shale, volcanic and } \\
\text { volcaniclastic rocks }\end{array}$ & OEm, Eva, Em, Evcf \\
\hline
\end{tabular}

The surficial hydrogeologic map and lithologic data from 187 drillers' logs were used to construct several hydrogeologic sections using A-Prime Software's CrossView ${ }^{\mathrm{TM}}$ for ArcGIS ${ }^{\circledR}$ to identify and correlate the hydrogeologic units in the subsurface. Four representative hydrogeologic sections are shown in plate 1 . Hydrogeologic units were assigned to the various lithologic layers depicted in each well log. Hydrogeologic unit assignments were used to delineate the extent of each unit throughout the study area. The elevation of the unit top surface was interpolated in a Geographic Information System (GIS) at a $100 \mathrm{ft}$ interpolation grid cell size, using a method based on the Australian National University Digital Elevation Model (ANUDEM) procedure developed by Hutchinson (1989). Hydrogeologic unit top surfaces were constrained to a LiDAR-derived land-surface digital elevation model (DEM) where the unit cropped out. In areas where interpolation over long distances resulted in the intersection of the top surfaces, minimum thickness values for the overlying unit were used to adjust the elevation of the top of the underlying unit downward where needed. Unit thickness maps were created by using GIS to calculate the difference between the top of a unit and the interpolated top of the underlying unit(s). 


\section{Streamflow}

Streamflows were measured on July 10, 2007, at 13 of the 14 sites (pl. 1) previously measured (June 26, 2002 and October 22, 2002) by Simonds and others (2004) to quantify groundwater discharge to streams during low-flow conditions, and to identify gaining and losing stream reaches. Streamflow was not measured at one site (CS10) due to lack of access. To calculate streamflow (discharge), the velocity of water is multiplied by the cross-sectional area of the stream (stream depth times stream width) using the integrated-cross-section method described by Rantz and others (1982). Most velocity measurements were made using either a Price AA current meter or a Swoffer Model 2100 horizontal-axis current meter. Side-by-side comparisons of the two meters yielded differences of less than 3 percent (Simonds and others, 2004). Small tributary streams with flows less than $0.5 \mathrm{ft}^{3} / \mathrm{s}$ were measured using either a pygmy meter, or by simply timing the fill of a 5-gallon bucket.

\section{Hydrogeologic Framework}

This section describes the geology and hydrogeologic framework that together define the physical, lithologic, and hydrologic characteristics of the hydrogeologic units that compose the groundwater system in the study area. An understanding of these characteristics is important in determining the occurrence, movement, and availability of groundwater within the aquifer system, and the exchange of water between the aquifer system and surface-water features.

\section{Geologic Setting}

The following brief summary of major geologic events in the study area is based on the work of Easterbrook (1979), Tabor and Cady (1978), Grimstad and Carson (1981), and Simonds and others (2004). Tectonic forces related to subduction of oceanic crust beneath the western coast of North America resulted in uplift and accretion of Eocene to Oligocene sedimentary and igneous rocks along the continental margin. These deformed rocks form the bedrock beneath the study area in eastern Jefferson County. The Puget
Lobe of the Cordilleran ice sheet advanced into the study area several times during the Pleistocene Epoch. The most recent period of glaciation, the Vashon Stade of Fraser glaciation, began about 17,000 years ago when the continental ice sheet in Canada expanded, and the Puget Lobe advanced southward, eventually covering the entire Puget Sound basin before halting and retreating. Unconsolidated deposits of glacial and interglacial origin are present throughout the study area. A typical glacial sequence progresses from advance outwash, to till, to recessional outwash. Fluvial, lacustrine, bog and marsh depositional environments were common during interglacial periods. The modern-day drainage pattern of Chimacum Creek is largely determined by pre-existing drainage pathways established by Vashon recessional outwash channels.

\section{Hydrogeologic Units}

The six hydrogeologic units defined for this study and described in the following six subsections are reinterpretations of the hydrogeologic units delineated by Simonds and others (2004); they consist of unconsolidated aquifers and confining units, along with an underlying bedrock unit (table 1). Glacial deposits are heterogeneous, and although a glacial aquifer may be composed primarily of sand or gravel, it may locally contain varying amounts of clay or silt. Conversely, a confining layer composed predominantly of silt or clay may contain local lenses of coarse material. These localscale variations in lithology may influence the occurrence and movement of groundwater at a scale that probably is too small to be adequately represented by the hydrogeologic framework constructed for this study. Local-scale variability in the distribution of glacial depositional facies often results in the formation of spatially discontinuous units of varying thickness. Therefore, most units are not aerially contiguous throughout the study area, and unit thickness may vary considerably over short distances. In the study area, aquifers consist primarily of coarse-grained glacial outwash but they also may include coarse-grained sediments within glacial till, and coarse-grained interglacial deposits. The confining units consist primarily of fine-grained glacial outwash, unsorted and compacted glacial till, glaciolacustrine deposits, and fine-grained interglacial deposits. Unconsolidated aquifer and confining units are underlain by low-permeability Eocene to Oligocene sedimentary and igneous bedrock. 
Upper Confining Unit (UC). - The Upper Confining unit is present at the surface along portions of Chimacum and East Fork Chimacum Creeks (pl. 1). The primary geologic unit that makes up the confining unit is the Quaternary alluvium (Qa). These Holocene-age alluvial deposits include silt, sand, and peat that occur primarily in flat valley bottoms and small lake basins, dune and beach sands, and small landslide deposits. In addition to Qa deposits, some fine-grained (silt and clay) Vashon recessional outwash deposits (Qvr) were included in the Upper Confining unit. Within the study area, the Upper Confining unit consists of very poorly drained, organic-rich deposits. Although they may be saturated for much of the year, these alluvial deposits are not a good source of water because they are either too fine-grained to yield water or too rich in organic matter to be useful for household use. The peat deposits in the Chimacum Creek Valleys have low permeability and therefore act as a barrier to surface water and groundwater exchange (Simonds and others, 2004). The Upper Confining unit was calculated to range from 5 to $50 \mathrm{ft}$ in thickness, with an average thickness of $27 \mathrm{ft}$ (fig. 2).

Upper Aquifer (UA).--Most of the Upper Aquifer is found in the bottoms of the main drainages with additional isolated remnants in depressions on the till surface (pl. 1). The aquifer is predominantly Vashon recessional outwash (Qvr) and coarse-grained Vashon till (Qvt) geologic units composed of stratified sand and gravel that were deposited as the Pleistocene-age Vashon ice sheet retreated northward; however, due to the inherent heterogeneity of glacial deposits, areas of fine-grained silt and clay are likely to be found within the Upper Aquifer. The coarse-grained sediments generally are water bearing and may form an unconfined water-table aquifer when not overlain by the Upper Confining unit. Thicknesses of the Upper Aquifer was calculated to range from 5 to $68 \mathrm{ft}$ in the area north of the community of Chimacum, with an average thickness of $18 \mathrm{ft}$ (fig. 3).

Middle Confining Unit (MC). - The Middle Confining unit is widespread throughout the uplands of the study area and is composed primarily of Vashon till (Qvt) and lesser amounts of the fine-grained Vashon recessional (Qvr) and fine-grained advance outwash (Qva) geologic units (pl. 1).
Glacial till is considered a low-permeability unit because of the unsorted and unstratified nature of the deposits. Depending on the method of deposition, the sediments that make up the Middle Confining unit (clay, silt, sand, and gravel) vary in the degree of compaction and may include some locally occurring sand and gravel lenses that are capable of providing water for domestic use. Thicknesses of the Middle Confining unit was calculated to range from 4 to $351 \mathrm{ft}$, with an average thickness of $48 \mathrm{ft}$ (fig. 4).

Lower Aquifer (LA). - The Lower Aquifer is present in the subsurface throughout much of the study area with surface exposures along slopes and along walls of incised stream valleys (pl. 1). The unit primarily is composed of Vashon advance outwash (Qva) but also may include some coarse sediments from the Vashon till (Qvt). The Lower Aquifer consists of stratified sand and gravel with lenses of silt and clay. The Lower Aquifer is the most prolific water-bearing unit in the area. It was calculated to range in thicknesses from 5 to $310 \mathrm{ft}$, with an average thickness of $61 \mathrm{ft}$ (fig. 5).

Lower Confining Unit (LC).- The Lower Confining unit is widespread in the subsurface of the study area with limited surface exposure along valley walls (pl. 1). It is composed primarily of undifferentiated older unconsolidated deposits (Qgo) that include pre-Vashon glacial deposits and interglacial fine-grained silts and clays. The great amount of spatial variability in this unit results from the complex depositional environments and the subsequent reworking of the sediments. There are coarse-grained, water-bearing zones but they lack lateral continuity and are therefore difficult to differentiate from other non-water-bearing zones. Thickness estimates were calculated by subtracting the top of bedrock (Jones, 1996) from the top of the Lower Confining unit, therefore computed thickness values range from $6 \mathrm{ft}$ to greater than $1,000 \mathrm{ft}$, with an average thickness of $372 \mathrm{ft}$ (fig. 6).

Bedrock (OE).-Bedrock crops out along the margins and the western interior of the study area (pl. 1). This bedrock of very low permeability consists of tectonically deformed Eocene to Oligocene sedimentary (sandstone, siltstone, shale, and conglomerate) and igneous (basalt and andesite flows and breccias) rocks. Where it is fractured, the bedrock locally yields usable quantities of water. 


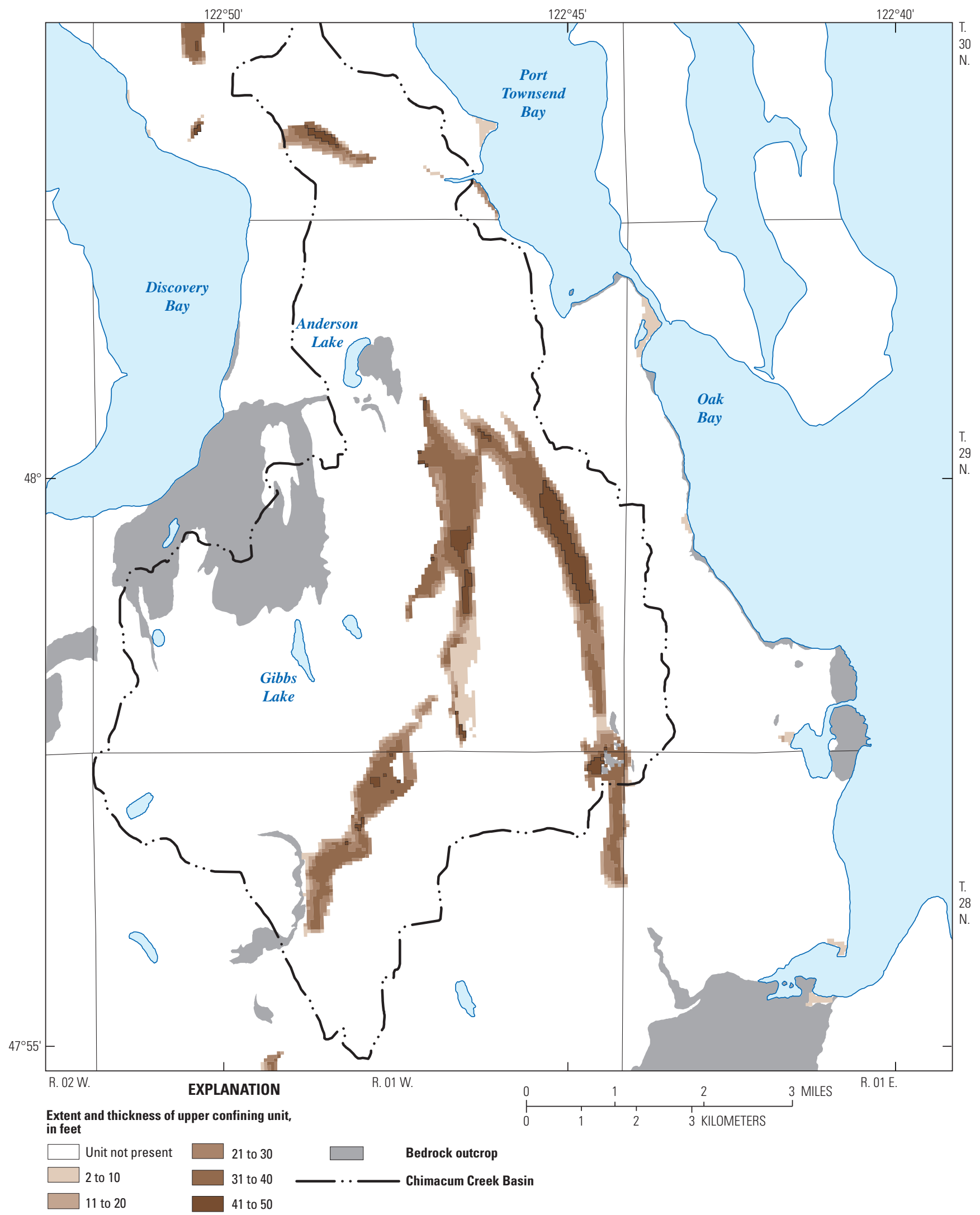

Figure 2. Extent and thickness of Upper Confining unit (UC) in Chimacum Creek basin and vicinity, Washington. 


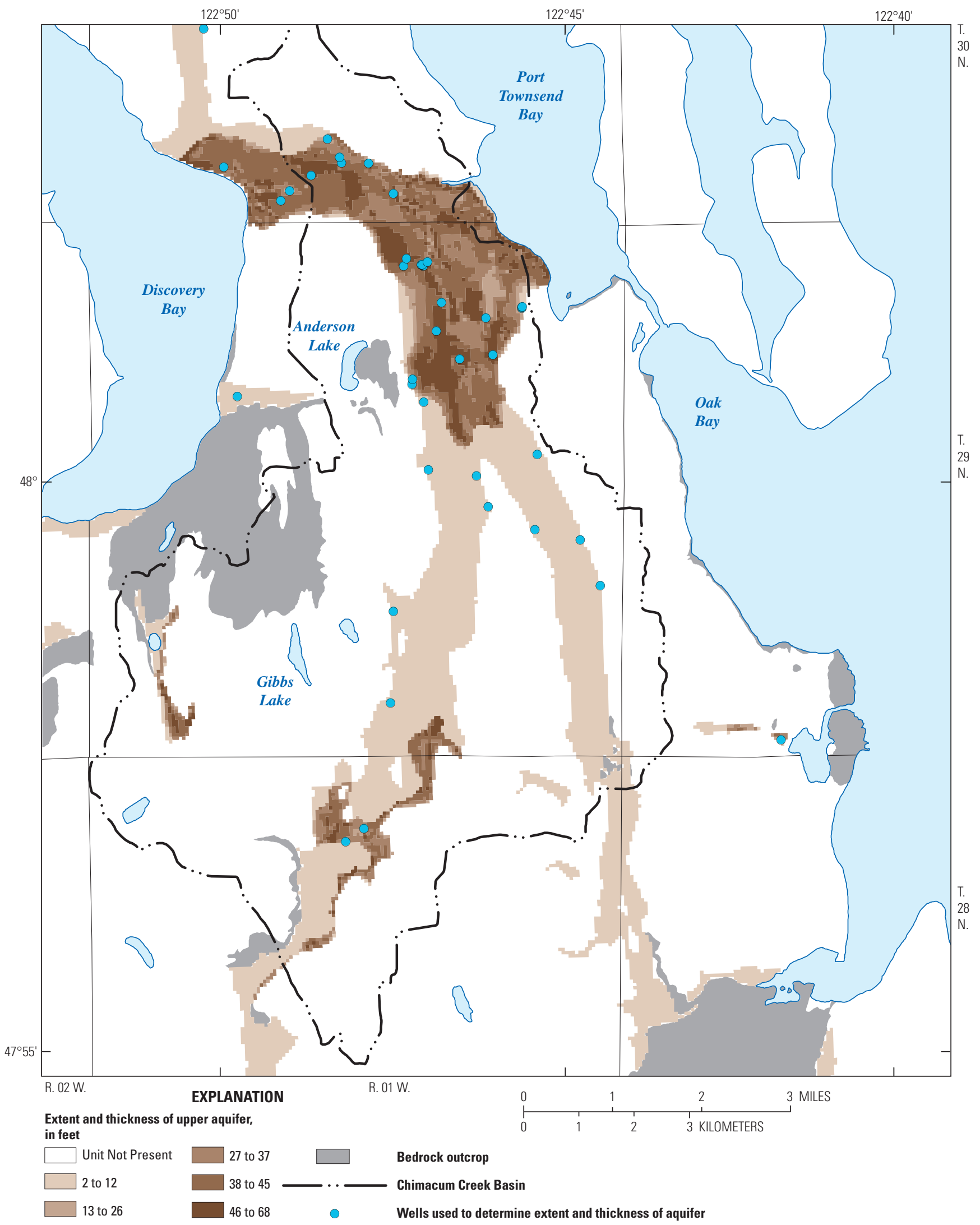

Figure 3. Extent and thickness of Upper Aquifer unit (UA) in Chimacum Creek basin and vicinity, Washington. 


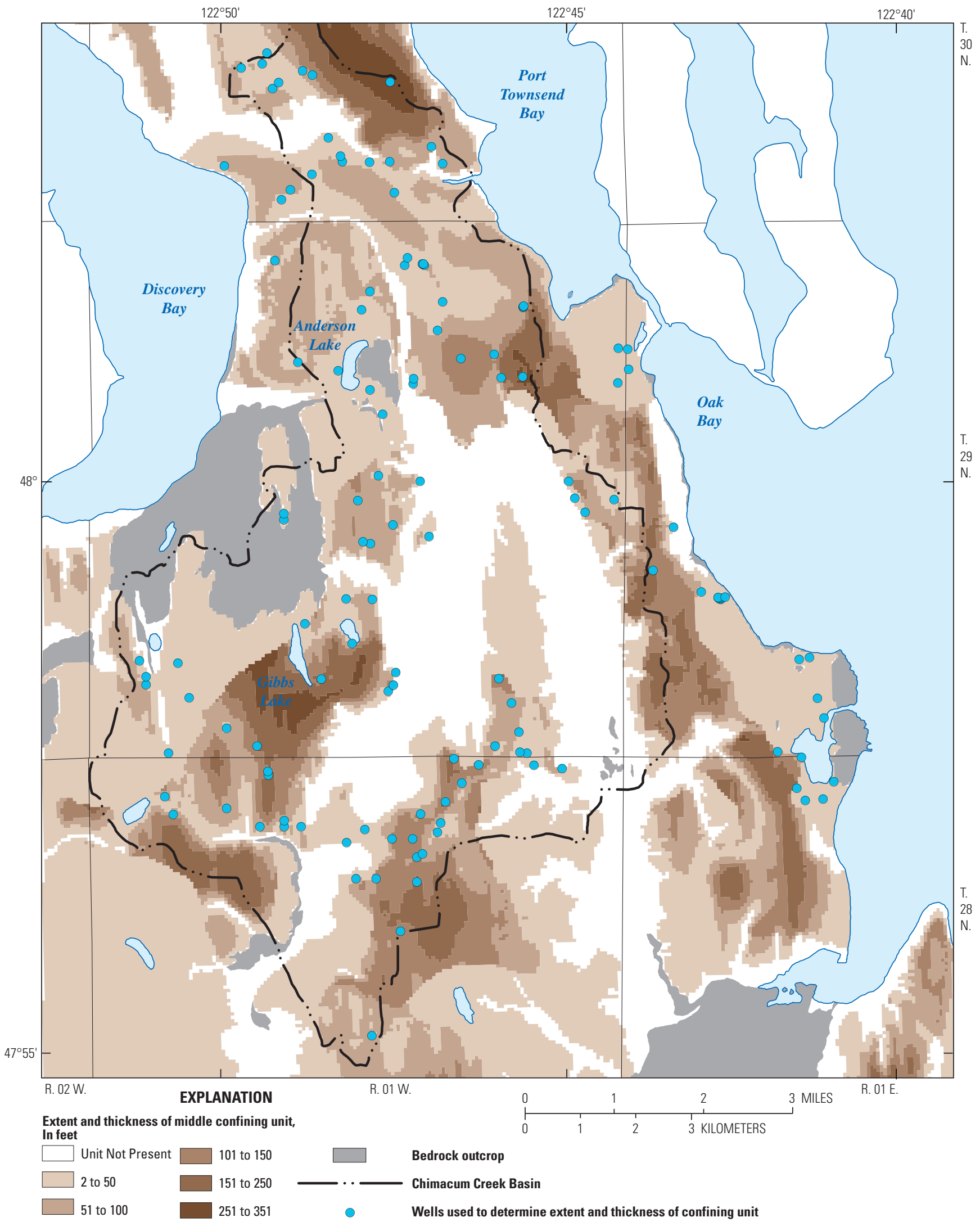

Figure 4. Extent and thickness of Middle Confining unit (MC) in Chimacum Creek basin and vicinity, Washington. 


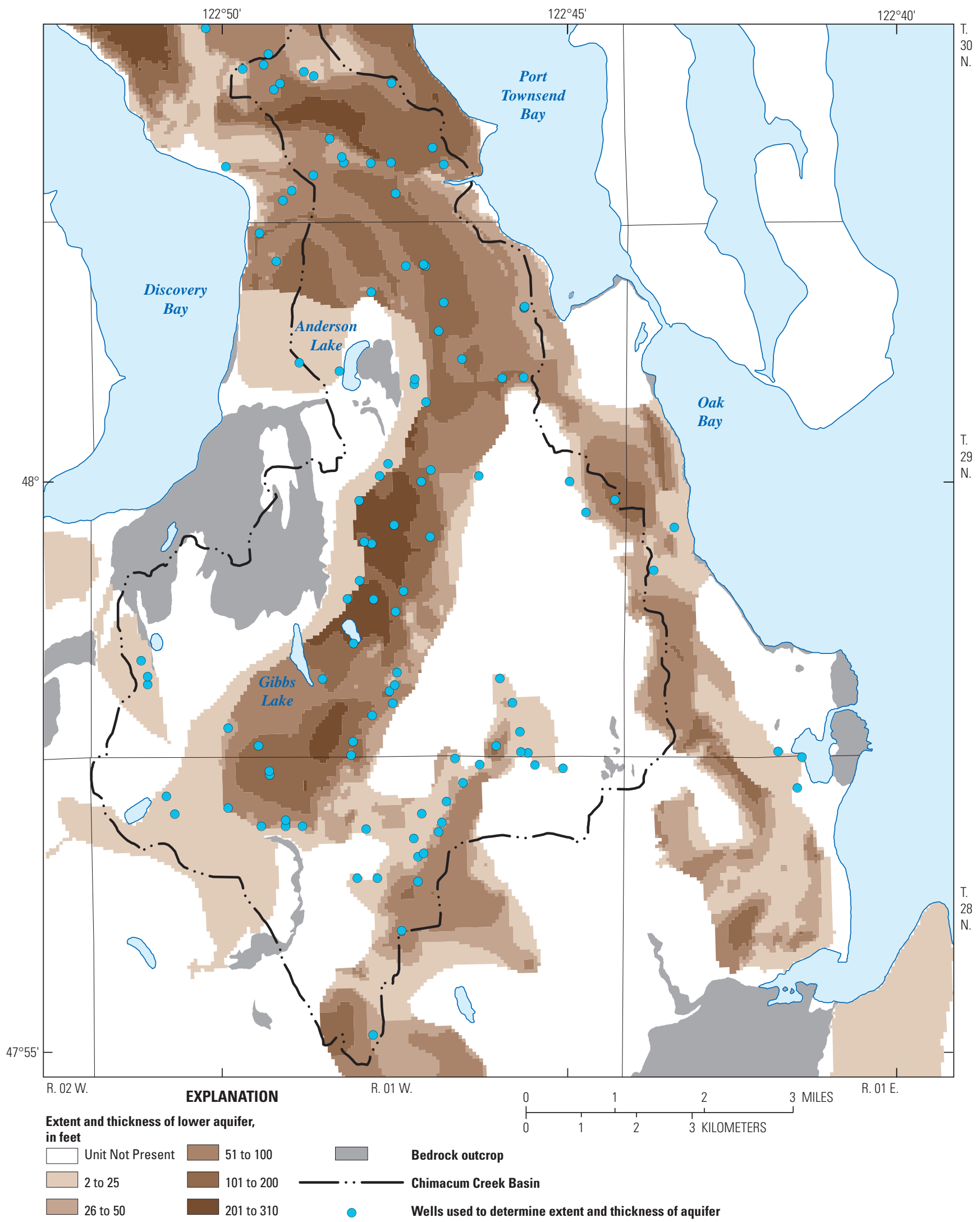

Figure 5. Extent and thickness of Lower Aquifer unit (LA) in Chimacum Creek basin and vicinity, Washington. 


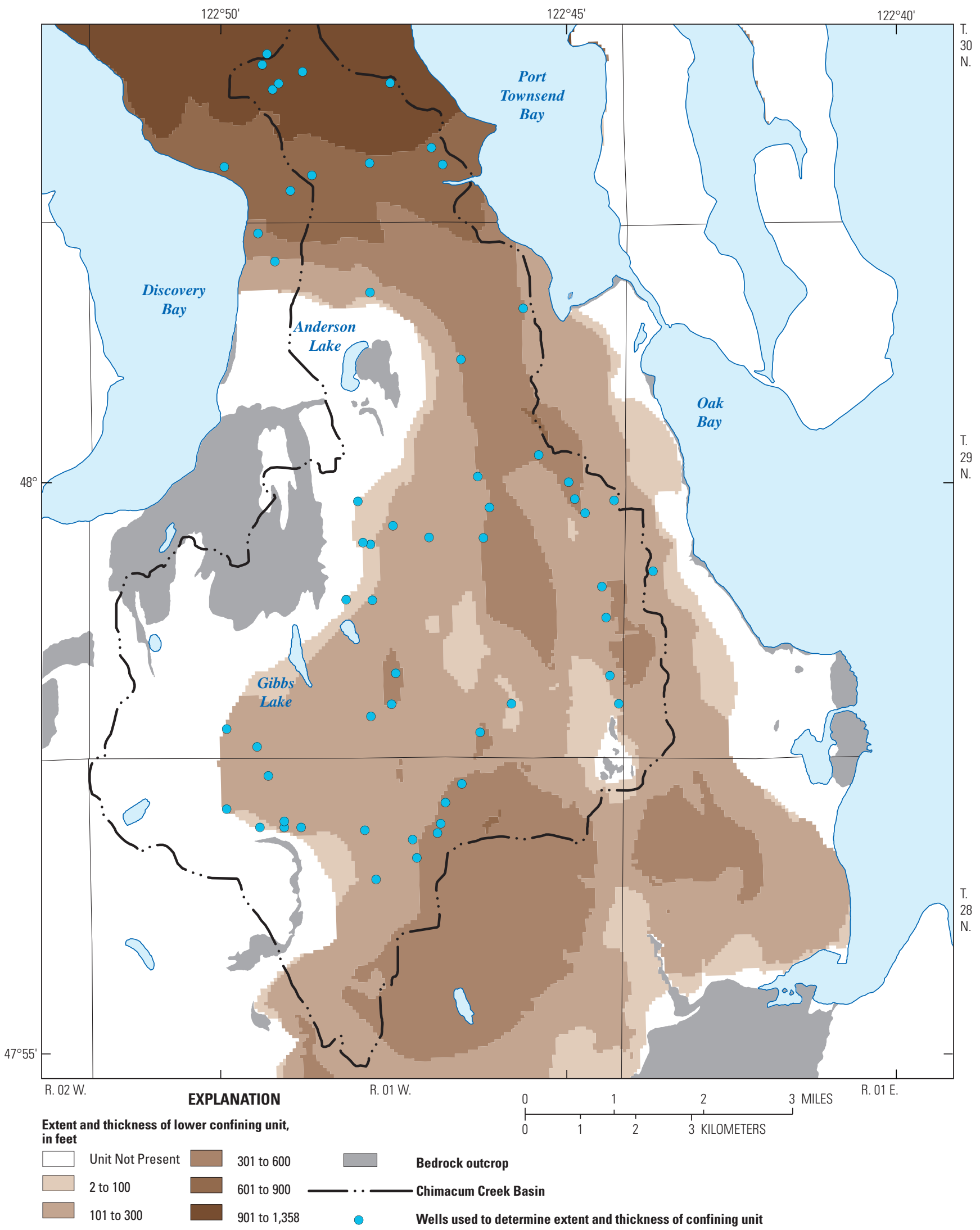

Figure 6. Extent and thickness Lower Confining unit (LC) of in Chimacum Creek basin and vicinity, Washington. 


\section{Groundwater Movement}

This section describes the movement of groundwater into and within the aquifer system in the study area, and discusses the following processes: groundwater recharge, flow direction, discharge to surface water, exchange of water between the aquifer system and streams, and temporal fluctuations in groundwater levels. These processes occur within the physical domain that the hydrogeologic framework describes, and they are influenced by the hydrogeologic characteristics of the aquifer system in which they occur, as well as by streamflow, and the spatial distribution of precipitation and land cover.

\section{Estimates of Groundwater Recharge}

Estimates of groundwater recharge were made for natural sources (precipitation) and for anthropogenic sources (return flows from water use). For natural sources, a regional precipitation-recharge relation was used to estimate areally distributed monthly recharge. For anthropogenic sources, recharge was estimated based on Jefferson County Public Utility District (PUD) \#1 delivery data inside the service are, census estimates of population distribution outside the PUD service area, and irrigation water-use estimates and land-use records.

\section{Recharge from Precipitation}

Precipitation is the dominant source of water that recharges the groundwater system in the study area, and variations in recharge can therefore be expected to be related to spatial and temporal variations in precipitation. However, the permeability of surficial hydrogeologic units and the characteristics of land cover also affect recharge; therefore, the relation between precipitation and recharge also is likely to vary according to hydrogeologic and land-cover characteristics.

The distribution of recharge from precipitation in the study area was estimated by applying precipitation-recharge relations based on regression equations that Bidlake and Payne (2001) developed for areas in Washington State. These equations incorporate the effects of surficial hydrogeology and the characteristics of tree canopy. The effects of impervious surfaces on the distribution of recharge from precipitation also were estimated in the study area.

Annual mean precipitation totals (fig. 7) were calculated from daily values for October 1, 1994 through September 31, 2009, which were produced using the Parameter-elevation Regressions on Independent Slopes Model method (PRISM,
Daly and others, 1994) and obtained at http://www.prism. oregonstate.edu (Oregon State University, 2009). The PRISM model estimates the distribution of normal annual precipitation based on a statistical method that takes into account elevation of the land surface and spatial variation.

The basin received about 284,000 acre-ft or about 56 in. of precipitation during an average year for water years 1995-2009.

The effects of surficial hydrogeology on the distribution of recharge from precipitation were estimated based on regression equations developed by Bidlake (Bidlake and Payne, 2001, fig. 8) for soils in western Washington formed on glacial outwash and alluvial sediments, and for soils formed on glacial till and fine-grained sediments. Recharge estimates for aquifer units (outwash and alluvium) exposed at land surface in the study area were based on the regression equation developed for soils formed on glacial outwash and alluvial sediments; recharge estimates for confining units (till and lacustrine) were based on the regression equation developed for soils formed on glacial till and fine-grained sediments. Recharge estimates for areas where sedimentary and bedrock units are exposed at land surface required the the study to approximate additional precipitation-recharge equations for this study that were based on a qualitative comparison of the hydrogeologic properties of unconsolidated, sedimentary, and bedrock units. Recharge characteristics of the sedimentary aquifer were estimated to be less than those of unconsolidated aquifers and greater than those of unconsolidated confining units, and a precipitation-recharge relation was selected for the sedimentary aquifer that plots midway between those of these two unconsolidated units (fig. 8). Recharge characteristics of the bedrock unit were estimated to be less than the unconsolidated confining units, and a precipitationrecharge relation was selected for the bedrock unit that represents half the recharge of the unconsolidated confining units.

The effect of evaporative loss on recharge from precipitation associated with the interception of precipitation by tree canopy on recharge from precipitation was estimated for unconsolidated and bedrock aquifers using equations from Bidlake and Payne (2001), and tree canopy distribution data obtained from the National Land Cover Database, NLCD, (2001). Interception loss was applied to areas with more than 50 percent tree canopy. Urban centers in the study area manage storm water by discharging runoff to rivers or streams rather than allowing it to infiltrate to groundwater. The study therefore reduced recharge within city limits, according to calculations of the percentage of impervious surface derived from the NLCD (2001). No direct recharge from precipitation was assumed for areas covered by lakes. 


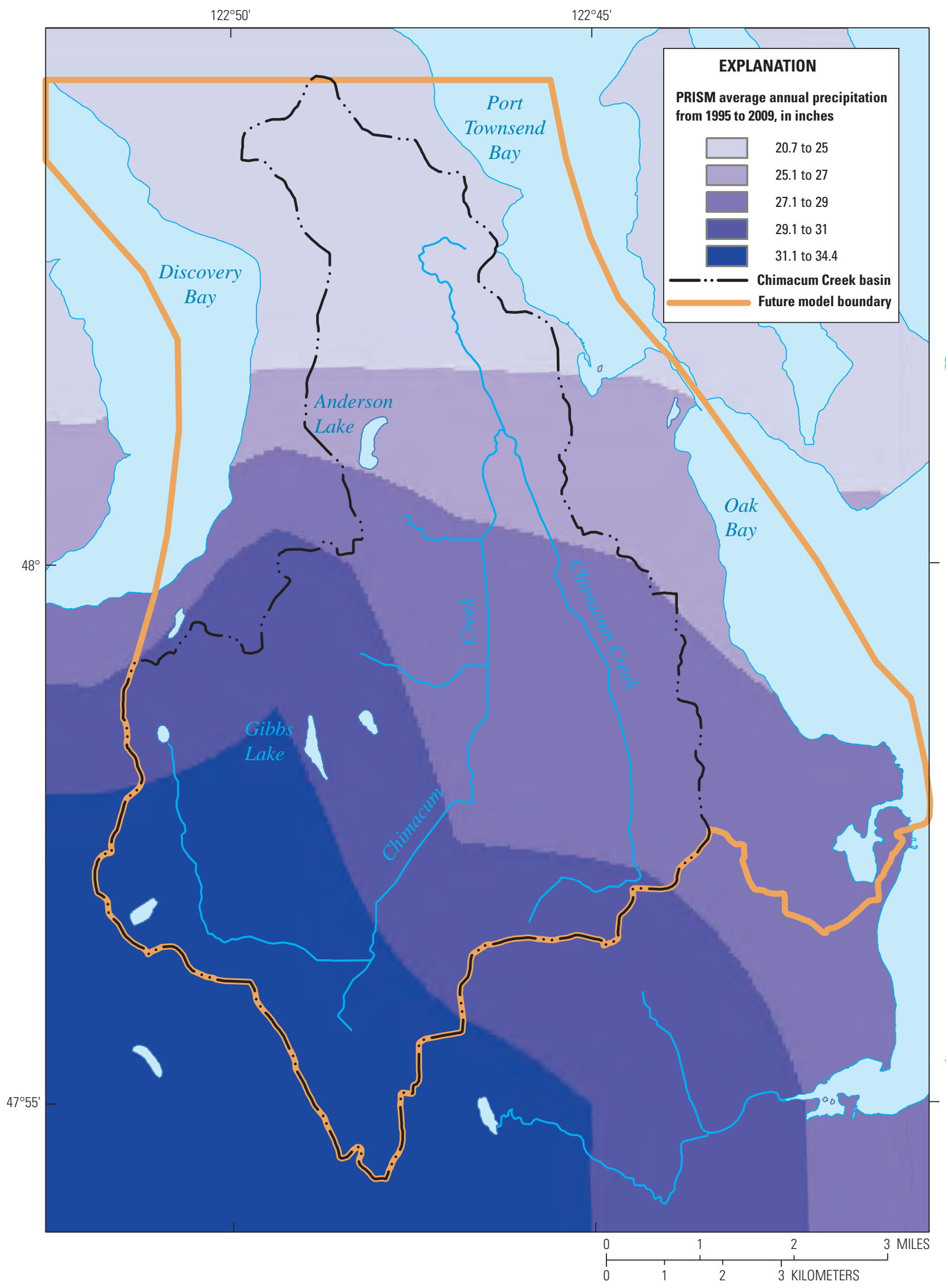

Figure 7. Average annual precipitation in the Chimacum Creek basin and vicinity, Washington, water years 1995-2009. 


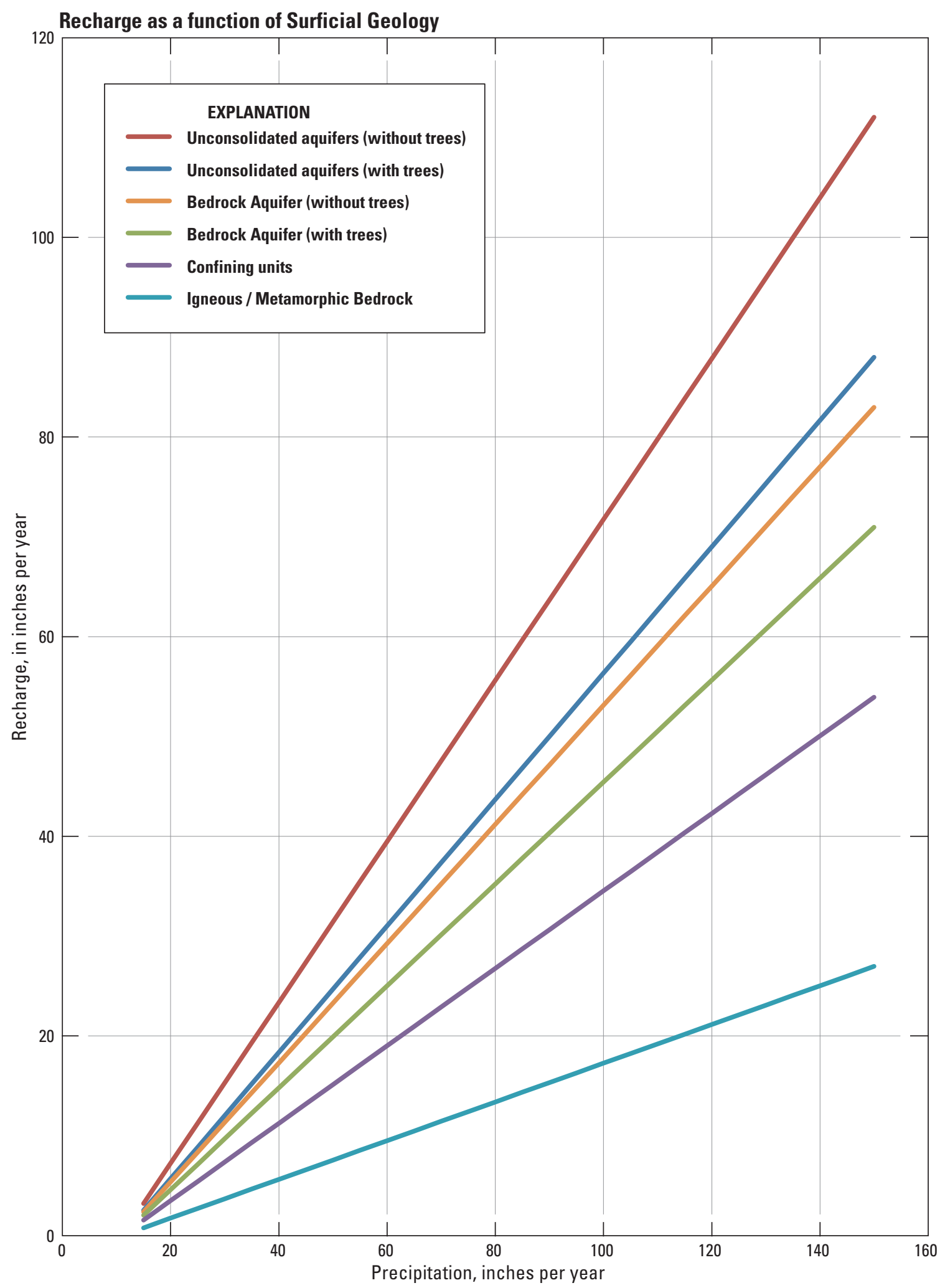

Figure 8. Precipitation-recharge relations used in this study, Chimacum Creek basin, Washington. 
GIS techniques were used to combine the data, thus enabling the study to calculate the distribution of groundwater recharge from precipitation at a $200 \mathrm{ft}$ cell size (fig. 9). Recharge rates range from less than $1 \mathrm{in} / \mathrm{yr}$ in urban areas underlain by impervious surfaces, to about $17 \mathrm{in} / \mathrm{yr}$ in the southwest part of the study area where the highest annual precipitation occurs.Total estimated average annual recharge from precipitation was 15,600 acre-ft, or $5.52 \mathrm{in/yr}$. In addition to groundwater recharge from precipitation, groundwater recharge from creeks also occurs within the study area along losing creek reaches. The total amount of groundwater recharge from creeks was not quantified, but is reflected in the computation of the total net groundwater discharge to creeks used in the section, "Groundwater Budget” (p. 25).

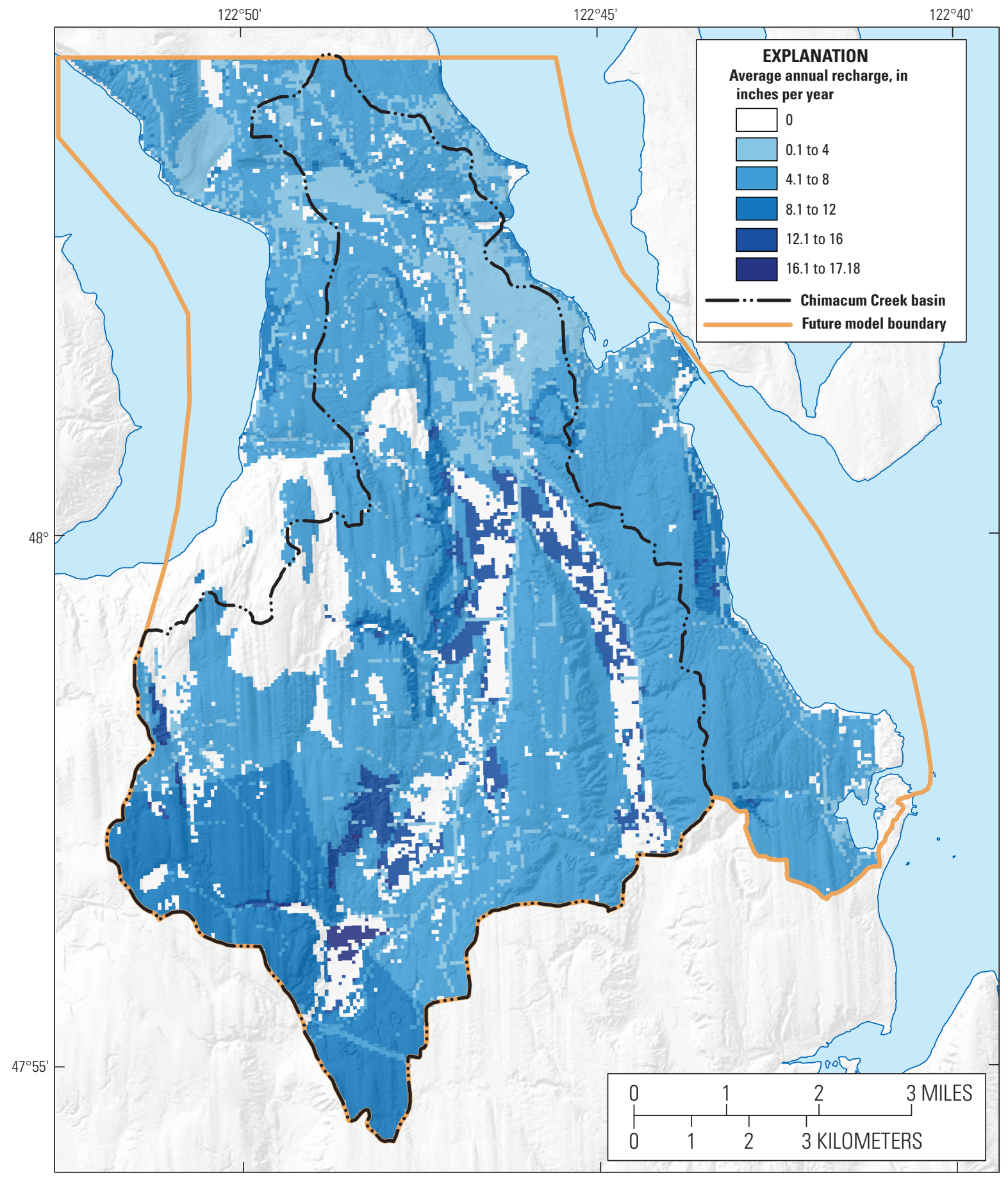

Figure 9. Average annual recharge from precipitation in the Chimacum Creek basin and vicinity, Washington, 1995-2009. 


\section{Anthropogenic Recharge}

Water use by humans also generates groundwater recharge from application of water to the land surface. In the Chimacum Creek basin this includes septic systems and irrigation (whether outdoor domestic, or agricultural). Consumptive use rates for indoor domestic use was set at 10 percent, consumptive use rates for outdoor domestic and agricultural use was set at 90 percent (Washington State Department of Ecology, 2009).

In order to estimate anthropogenic recharge, the PUD \#1 records for domestic water use (table 2, Bill Graham, PUD \#1, written commun.) were used directly for its service area (fig. 10) and distributed evenly in time and throughout the service area during 1994-2009. Outside the service area, estimates for water use were distributed over nonagricultural parcels using 2005 census data to estimate population and a self-supplied domestic use rate of $65 \mathrm{gal} / \mathrm{d}$ per person for year-round indoor use, 10 percent of which was assumed to be lost to evapotranspiration, with the remainder recharging to the top hydrogeologic unit. Additional water representing domestic outdoor use was applied during the summer growing season, during May through September (table 3), and assumed to be 90 percent of consumptive use. Table 2 combines total annual indoor and outdoor self-supplied domestic water use.

Agricultural irrigation return flows were distributed over agricultural parcels assuming 90 percent consumptive use. The study determined which areas could be expected to support irrigated agriculture (fig. 10) by using Washington Department of Agriculture records for township-range sections that contained irrigated agriculture, together with U.S. Census Bureau data identifying parcels used for agriculture (irrigated or not) during the same period. Assuming 90 percent consumptive use and an estimate of total self-supplied irrigation water of 250,800,000 gal/yr (Golder Associates, 2010), the average annual return flow to the top hydrogeologic unit from irrigated agriculture was calculated to be 77 acre-ft.
Table 2. Water use by residents within the Jefferson County Public Utility District \# 1 (public-supply use), and by residents outside the public-supply area (self-supplied use); and the resultant recharge of groundwater by return flow from each class of user, during each year of the recorded period 1994-2009.

[Values in acre-feet]

\begin{tabular}{ccccc}
\hline Year & $\begin{array}{c}\text { Public- } \\
\text { supply } \\
\text { amount }\end{array}$ & $\begin{array}{c}\text { Recharge } \\
\text { from } \\
\text { public } \\
\text { supply }\end{array}$ & $\begin{array}{c}\text { Self- } \\
\text { supplied } \\
\text { amount }\end{array}$ & $\begin{array}{c}\text { Recharge } \\
\text { from self } \\
\text { supplied }\end{array}$ \\
\hline 1994 & 791 & 566 & 174 & 118 \\
1995 & 796 & 570 & 180 & 122 \\
1996 & 799 & 571 & 183 & 124 \\
1997 & 670 & 481 & 184 & 124 \\
1998 & 800 & 570 & 187 & 127 \\
1999 & 761 & 552 & 190 & 128 \\
2000 & 765 & 544 & 192 & 133 \\
2001 & 791 & 564 & 198 & 137 \\
2002 & 833 & 588 & 201 & 139 \\
2003 & 900 & 634 & 204 & 141 \\
2004 & 892 & 631 & 206 & 143 \\
2005 & 870 & 614 & 210 & 146 \\
2006 & 908 & 638 & 215 & 149 \\
2007 & 906 & 640 & 216 & 150 \\
2008 & 894 & 635 & 219 & 151 \\
2009 & 959 & 669 & 219 & 152 \\
\hline
\end{tabular}

Table 3. Monthly mean indoor and outdoor water use rates for self-supplied domestic water use in the Chimacum Creek basin and vicinity, Washington, water years 1995-2005.

[Table values are in gallons per person per day]

\begin{tabular}{lcc}
\hline \multicolumn{1}{c}{ Month } & Indoor use & Outdoor use \\
\hline January & 65 & 0 \\
February & 65 & 0 \\
March & 65 & 0 \\
April & 65 & 0 \\
May & 65 & 23.3 \\
June & 65 & 65.0 \\
July & 65 & 76.2 \\
August & 65 & 76.2 \\
September & 65 & 58.7 \\
October & 65 & 1.2 \\
November & 65 & 0 \\
December & 65 & 0 \\
\hline
\end{tabular}




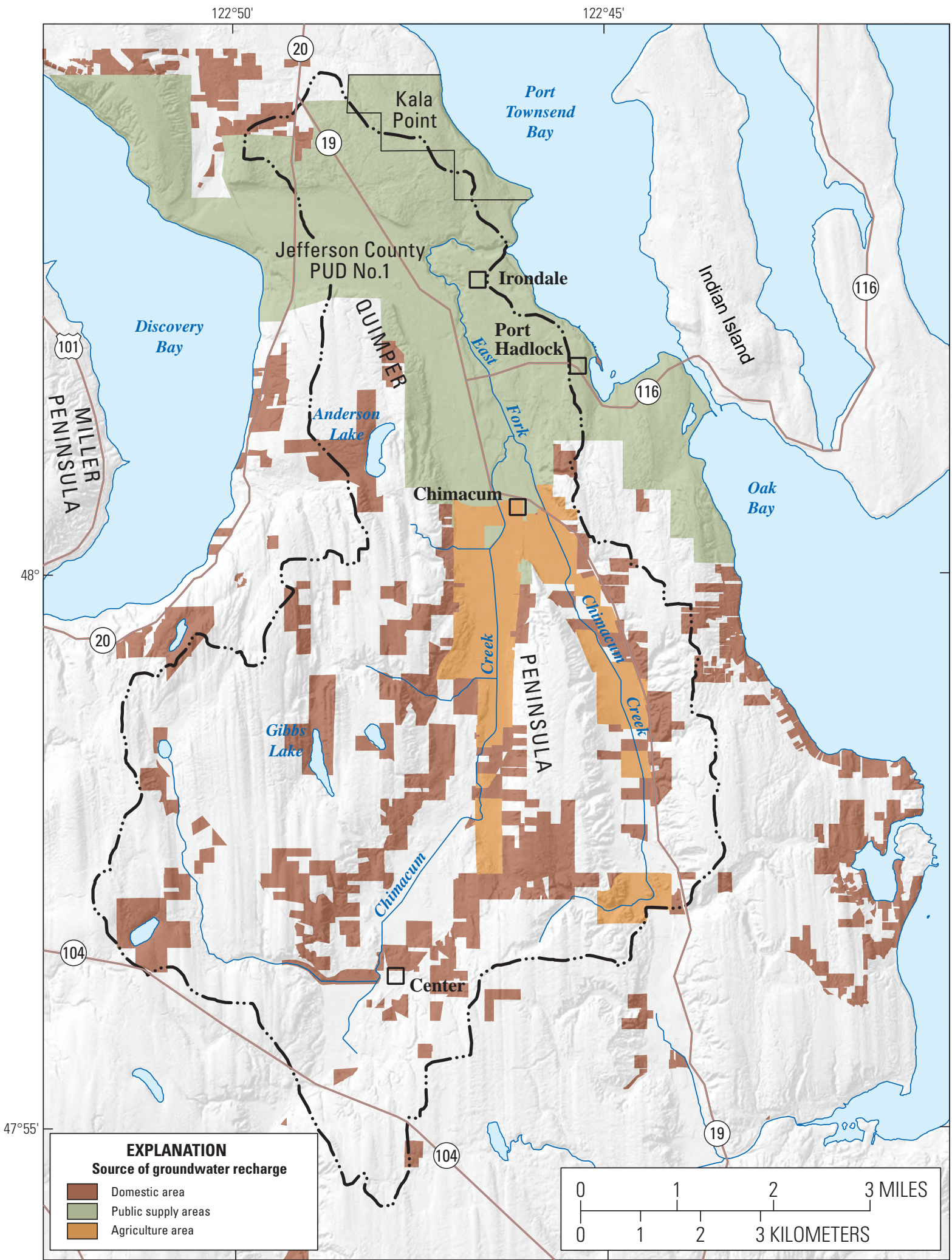

Base from U.S. Geological Survey and/or

Washington Division of Geology and Earth Resources

digital data, $1983,1: 100,000$

jection, Zone 10

Figure 10. Areas of groundwater recharge from public-supply, domestic and agricultural sources, Chimacum Creek basin and vicinity, Washington, water years 1995-2009. 


\section{Groundwater-Flow Directions}

Simonds and others (2004) used 110 field verified wells and their measured land surface altitudes to approximate groundwater table elevation and groundwater flow directions (fig. 11). The distribution of available wells from that study was limited by the very low population density and large areas with little access or development. No new field data collection from new wells was conducted for this study. For areas with no data, Simonds and others (2004) relied largely on the topography, which is reasonable given the local conditions. The western and eastern extents of the groundwater system are bounded by bedrock except near the mouth of Chimacum Creek. At the eastern extent, the topographic high suggests there should be a groundwater divide and seepage face discharge to either springs or evapotranspiration. A similar situation exists for the topographic high in the central part of the basin. The walls of the western and eastern valleys containing Chimacum Creek and East Fork Chimacum Creek have numerous springs discharging from areas where the Lower Aquifer and coarser facia of the Lower Confining unit are exposed. Where the Upper or Lower Aquifer units are exposed to Discovery Bay or to Port Townsend Bay, discharge from exposed units is likely.

\section{Groundwater Discharge}

Groundwater discharges include well withdrawals, discharge to streams, springs, and seeps, and submarine discharge to saltwater. Groundwater withdrawals from wells during 1994-2009 averaged 833 acre-ft for the PUD, 198 acre-ft for domestic wells, and 770 acre-ft for agricultural wells (Golder Associates, 2010). These quantities represent gross withdrawals (self-supplied domestic and public-water supply); they do not reflect the quantity of water returned to the groundwater system through septic systems, from outdoor domestic use, or from agricultural irrigation. For this study, self-supplied domestic groundwater use refers to groundwater withdrawn for indoor and outdoor single-household use that is outside of the service areas for public-water supply. Estimates for this category were made using monthly per capita rates from Golder Associates (2008) and census-block populations.
Public-water supply withdrawals were calculated for Jefferson County Water District's Quimper system by using monthly production values provided by the PUD (Bill Graham, Jefferson County Public Utility District, written commun., 2011). Withdrawal estimates for the Kala Point water system were made using monthly per-capita rates from Golder Associates (2008) and of inhabitants served numbers from the Washington State Department of Health, Office of Drinking Water (Washington State Department of Health, 2011). In addition to pumpage, groundwater discharges to Chimacum Creek, to its tributaries, and to springs. Spring discharges were not measured directly; spring discharge generally flows to tributaries and our study accounted for it in streamflow. Baseflow near the mouth of Chimacum Creek was used as a surrogate for net baseflow, and the study estimated average baseflow to be $6.36 \mathrm{ft}^{3} / \mathrm{s}$, or 4,600 acre-ft. Total accountable discharges to wells, streams, and springs is thus estimated to be 6,400 acre-ft.

\section{Groundwater and Surface-Water Interactions}

Synoptic streamflow measurements were conducted July 10, 2007, at the same sites in Chimacum Creek basin that Simonds and others (2004) measured in 2002 (table 4 and fig. 12); the discharges are comparable to the measurements made by Simonds and others (2004) in June 2002 and October 2002, except for the sites on the lower reaches of the East Fork (CS11; 12), and near the mouth (CS14), where the discharge was only one-half the average of the 2002 measurements.

Gains and losses (fig. 12) display trends that typically are associated with local topography: in the headwaters, the channels incised into the till plain show gains; losses occur along the long flat valley floors upstream of the confluence; and gains occur where the stream is conveyed in a steeper and incised reach that carries it to Port Townsend Bay. The 2002 measurements followed those general trends, as did the 2007 measurements, with the notable exception of site CS14, which averaged about $8 \mathrm{ft}^{3} / \mathrm{s}$ in 2002, but only about $4 \mathrm{ft}^{3} / \mathrm{s}$ in 2007 . Average annual baseflow near the mouth is $6.36 \mathrm{ft}^{3} / \mathrm{s}$, or about 4,600 acre-ft.

Table 4. Synoptic stream discharges in Chimacum Creek, Washington, measured on June 26, 2002, October 22, 2002, and July 10, 2007.

[2002 data from Simonds and others (2004). —, no data]

\begin{tabular}{|c|c|c|c|c|c|c|c|c|c|c|c|c|c|c|}
\hline Date & CS1 & CS2 & CS3 & CS4 & CS5 & CS6 & CS7 & CS8 & CS9 & CS10 & CS11 & CS12 & CS13 & CS14 \\
\hline June 26, 2002 & 0.84 & 0.17 & 2.38 & 2.76 & 4.37 & 0.32 & 0.14 & 3.90 & 0.62 & 1.47 & 1.60 & 1.38 & 6.30 & 7.10 \\
\hline October 22, 2002 & 0.79 & 0.13 & 2.85 & 3.09 & 4.32 & 0.36 & 0.14 & 4.69 & 0.74 & 1.71 & 1.72 & 1.45 & 7.22 & 8.89 \\
\hline July 10, 2007 & 0.31 & 0.15 & 2.27 & 3.10 & 3.54 & 0.05 & 0.07 & 2.50 & 0.64 & - & 0.39 & 0.80 & 7.90 & 4.13 \\
\hline
\end{tabular}




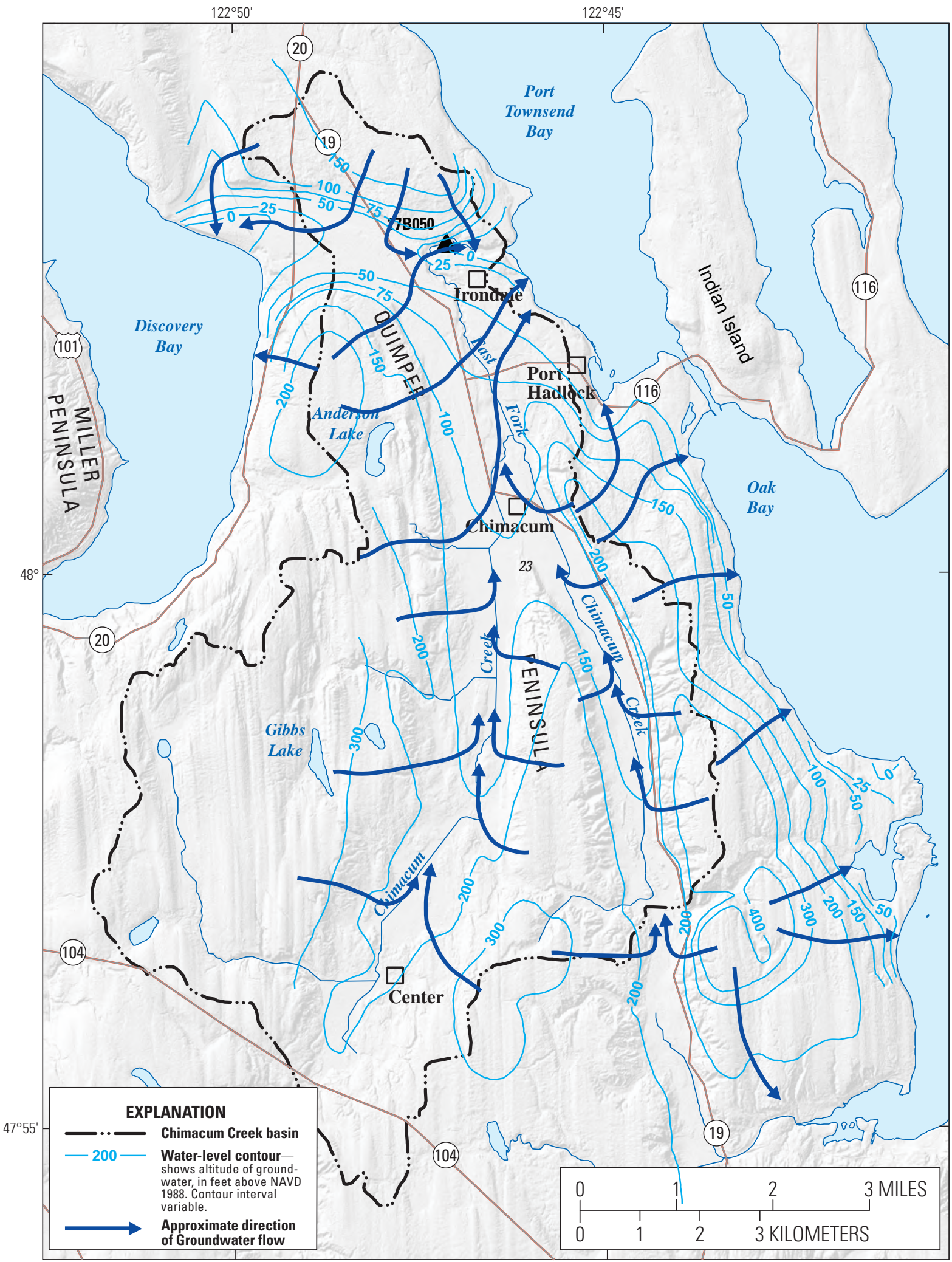

Base from U.S. Geological Survey and/or

Washington Division of Geology and Earth Resources

digital data, $1983,1: 100,000$

Zone 10

Horizontal Datum: North American Datum of 1927 (NAD 27)

Figure 11. Estimated water table elevation, water-level contours, and approximate directions of groundwater flow in the Lower Aquifer (LA) and Lower Confining (LC) units, Chimacum Creek basin and vicinity, Washington. (From Simonds and others, 2004.) 


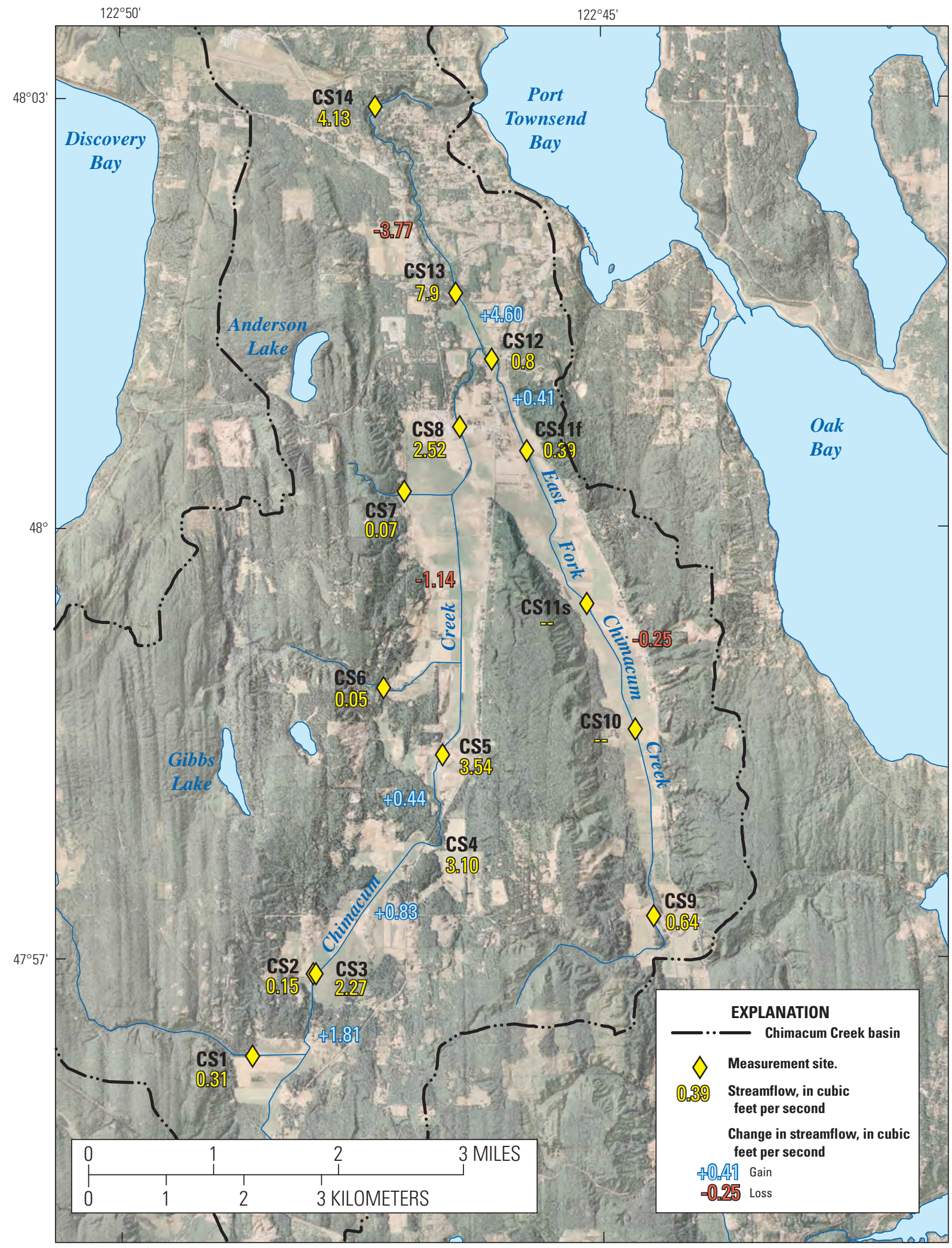

Base from U.S. Geological Survey and/or

Washington Division of Geology and Earth Resources

digital data, 1983, 1:100,000

Universal Transverse Mercator projection, Zone 10

Horizontal Datum: North American Datum of 1927 (NAD 27)

Figure 12. Synoptic streamflow measurements and gain/loss amounts, Chimacum Creek basin and vicinity, Washington, July 10, 2007. 


\section{Groundwater-Level Fluctuations}

Monthly water-level measurements were made by PUD \#1 during January 2008-May 2009 in eight monitoring wells at the same locations that Simonds and others (2004) studied during 2002-03 (fig. 13, table 5). Water-level elevations (fig. 14) generally were comparable with the following exceptions:

1. Well 35J01 (unit LC) water-level elevations were approximately $70 \mathrm{ft}$ higher during 2008-09, and showed a strong seasonal signal rather than a slow steady decline.

2. Well 04R01 (unit UA) showed a strong seasonal signal without the spike that Simonds and others (2004) reported for late summer 2002 spike that appears to mask what would otherwise have been a similar seasonal signal. This well is adjacent to a pond which the owner uses, and the earlier measurements possibly could have been affected if the owner had pumped deeper groundwater into the pond, raising shallow groundwater heads in the vicinity.

3. Well 23F01 (unit LC) appears to have been affected by unknown interference during 2008-09; the 2002-03 data showed large but temporary declines during summer and spring suggesting that local withdrawals may have masked any seasonal trend in both datasets.

4. Well 26M01 (unknown depth, but probably in unit UA, given its proximity to Chimacum Creek), also shows weak seasonal signals. This well is very near the mainstem Chimacum Creek and probably is showing a combination of a seasonal groundwater table signal, and flow conditions in the nearby stream.

5. Well unit (15B01) shows weak seasonal signals. This well is used intermittently for livestock and may reflect either local withdrawal or a measurement taken during recovery from recent pumping.

6. Well 15R01 (unit LA) shows a clearer seasonal response during 2002-03 and during 2008-09, but with a consistent late summer decline of $5-10 \mathrm{ft}$. This well is near a springfed tributary and also near the periphery of unit LA, either of which may be related to this non-seasonal signal.

7. Wells 03R01 (unit LA) and 24K03 (unit LC) both exhibit strong seasonal signals.

Table 5. Physical and hydrologic data for monitoring wells in the Chimacum Creek basin, Washington.

[Local well No.: See Well-Numbering System. Location of wells are shown on plate 1. Washington Dept. of Ecology tag: Washington Department of Ecology unique identification No. Hydrogeologic unit: LA, Lower aquifer, Till, and advance outwash deposits; LC, Lower confining unit, Undifferentiated glacial and inter-glacial deposits; UA, Upper aquifer, Recessional outwash and till. Latitude and longitude provided in degrees, minutes, seconds. LIDAR altitude: Landsurface altitude determined from LIDAR return signal. Primary use of water: H, domestic; I, irrigation; P, public supply; T, institutional; U, unused; and Z, other. Drillers' log available: N, no; Y, yes. Abbreviations: ft, foot; ft/d, foot per day. -, no data]

\begin{tabular}{lccccccccc}
\hline Local well No. & $\begin{array}{c}\text { Washington } \\
\text { Dept. of } \\
\text { Ecology tag }\end{array}$ & Latitude & Longitude & $\begin{array}{c}\text { Hydrogeologic } \\
\text { unit }\end{array}$ & & $\begin{array}{c}\text { LIDAR } \\
\text { altitude } \\
\text { (ft) }\end{array}$ & $\begin{array}{c}\text { Depth of Depth of } \\
\text { hole } \\
\text { (ft) }\end{array}$ & $\begin{array}{c}\text { Primary } \\
\text { well } \\
\text { (ft) }\end{array}$ & $\begin{array}{c}\text { Horizontal } \\
\text { use of } \\
\text { water } \\
\text { waulic } \\
\text { conductivity } \\
\text { (ft/d) }\end{array}$ \\
\hline Driller's log \\
available
\end{tabular}




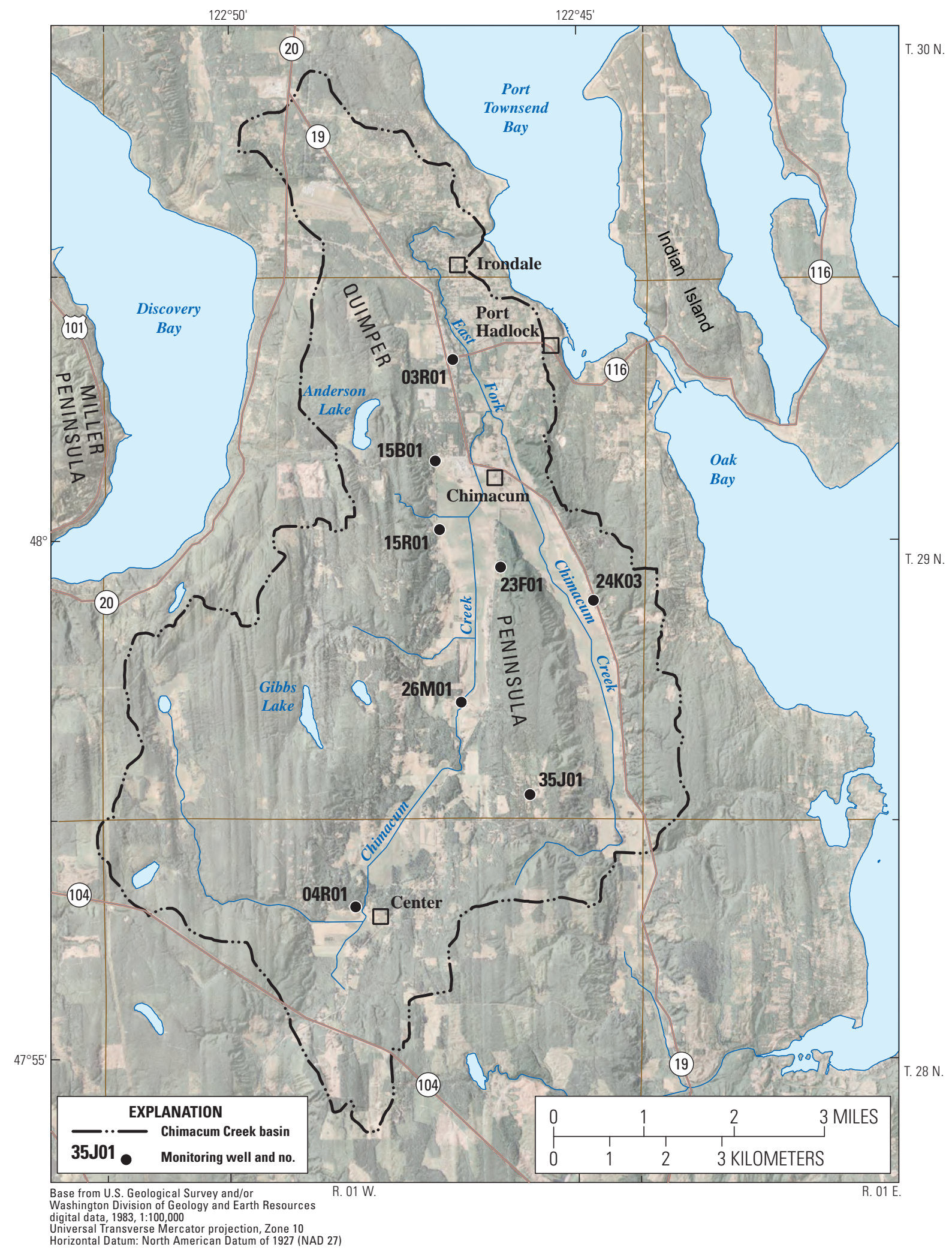

Figure 13. Locations of monitoring wells, Chimacum Creek basin and vicinity, Washington. 
A. 29N/01W-35J01

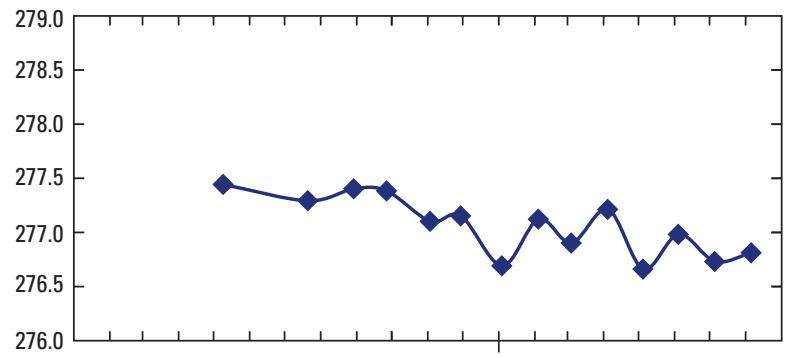

B. 28N/01W-04R01

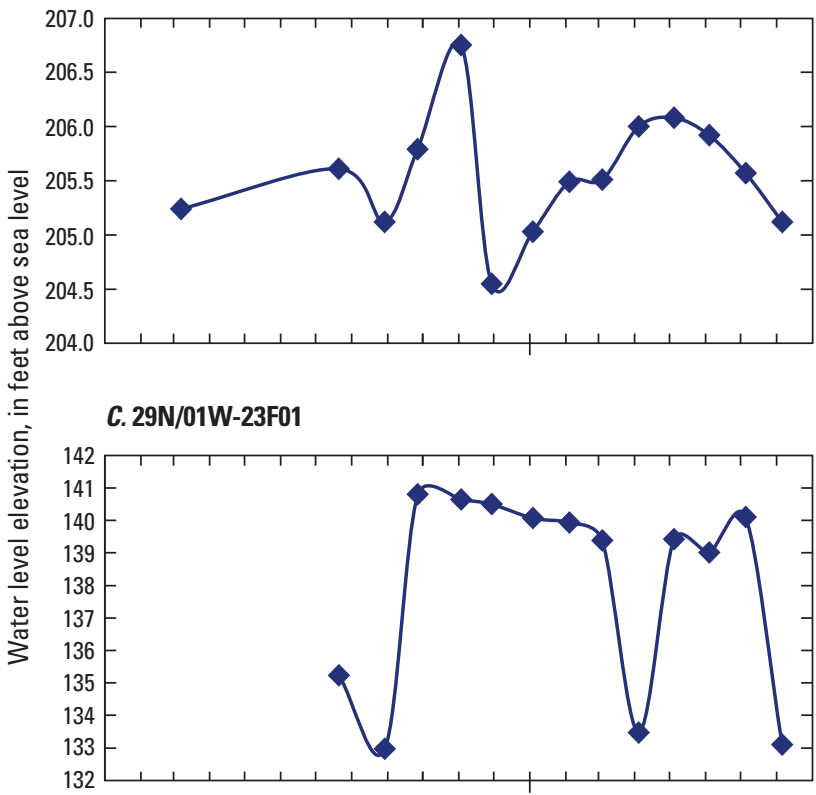

D. 29N/01W-26M01

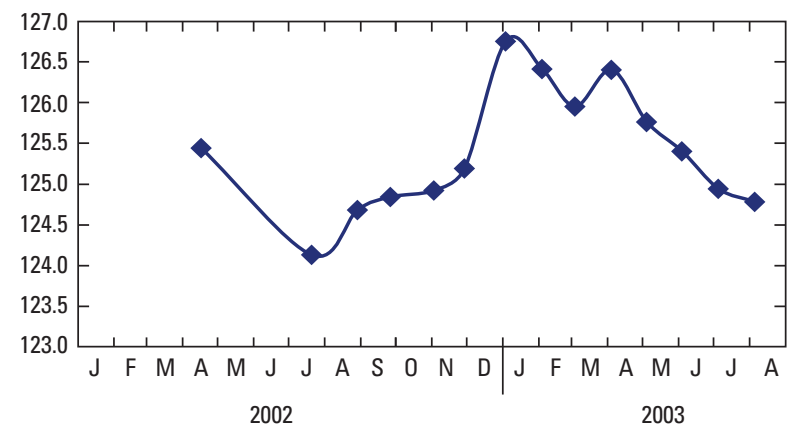

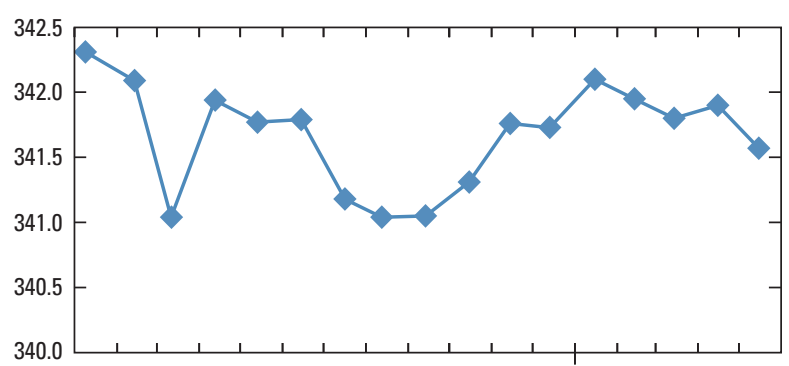
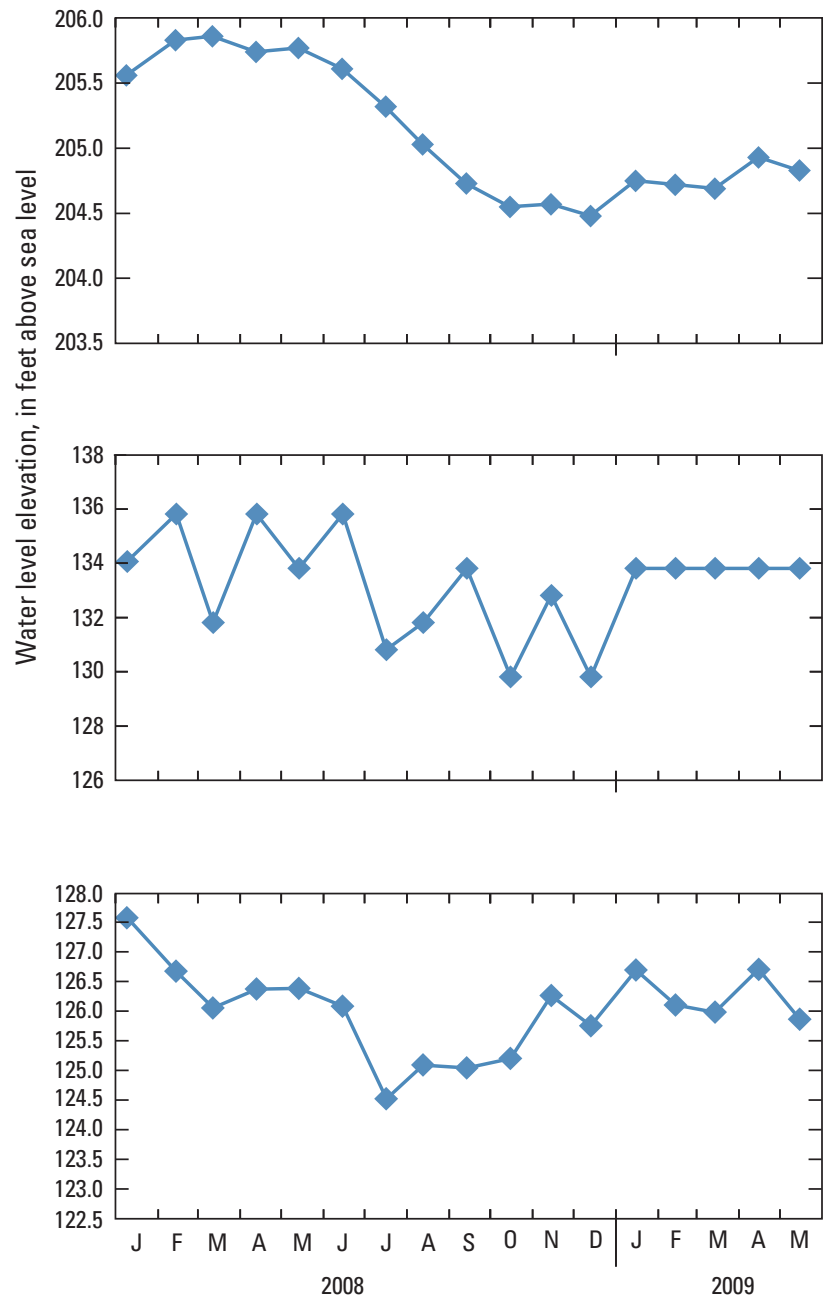

Figure 14. Water table elevations at monitoring wells in the Chimacum Creek basin and vicinity, Washington, for parts of 2002, 2003, 2008, and 2009. 


\section{E. 29N/01W-15B01}

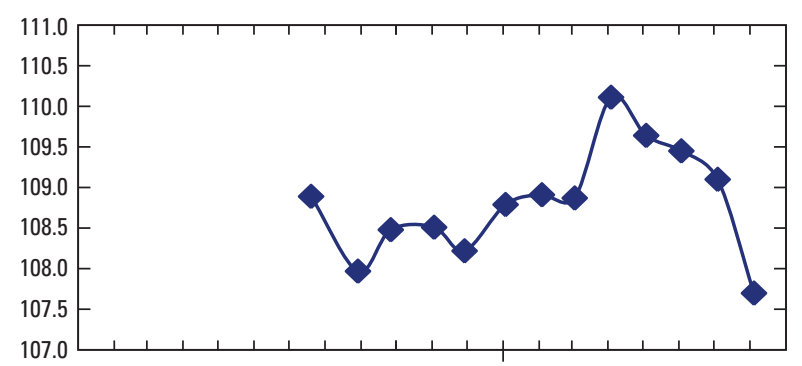

\section{F. 29N/01W-15R01}

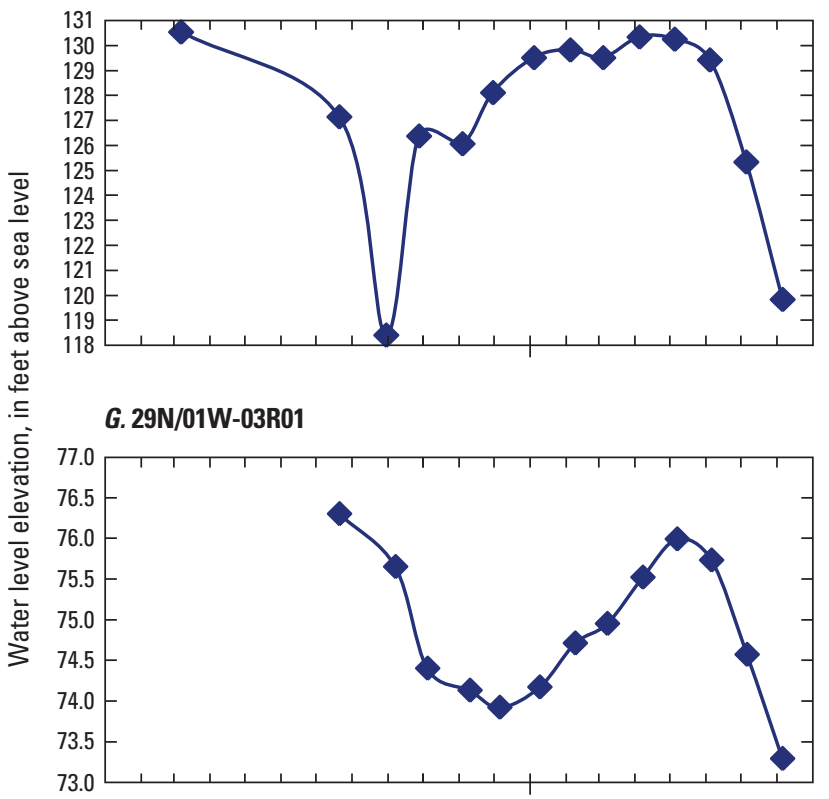

H. 29N/01W-24K03

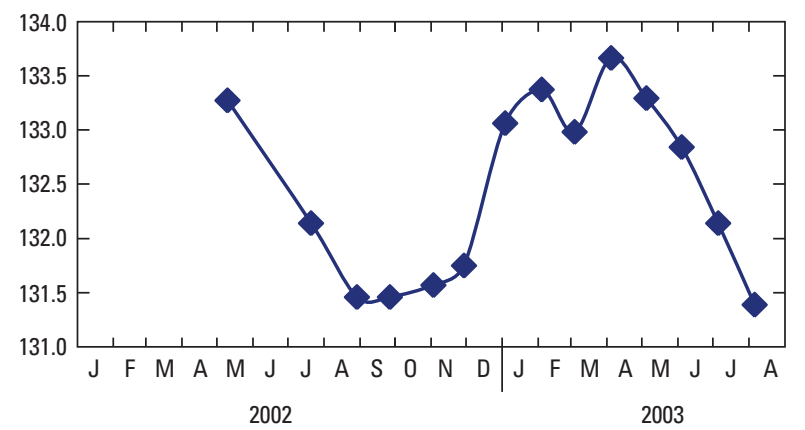

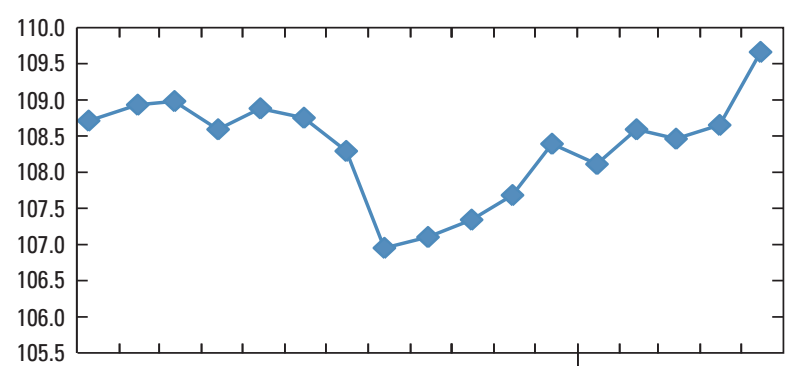
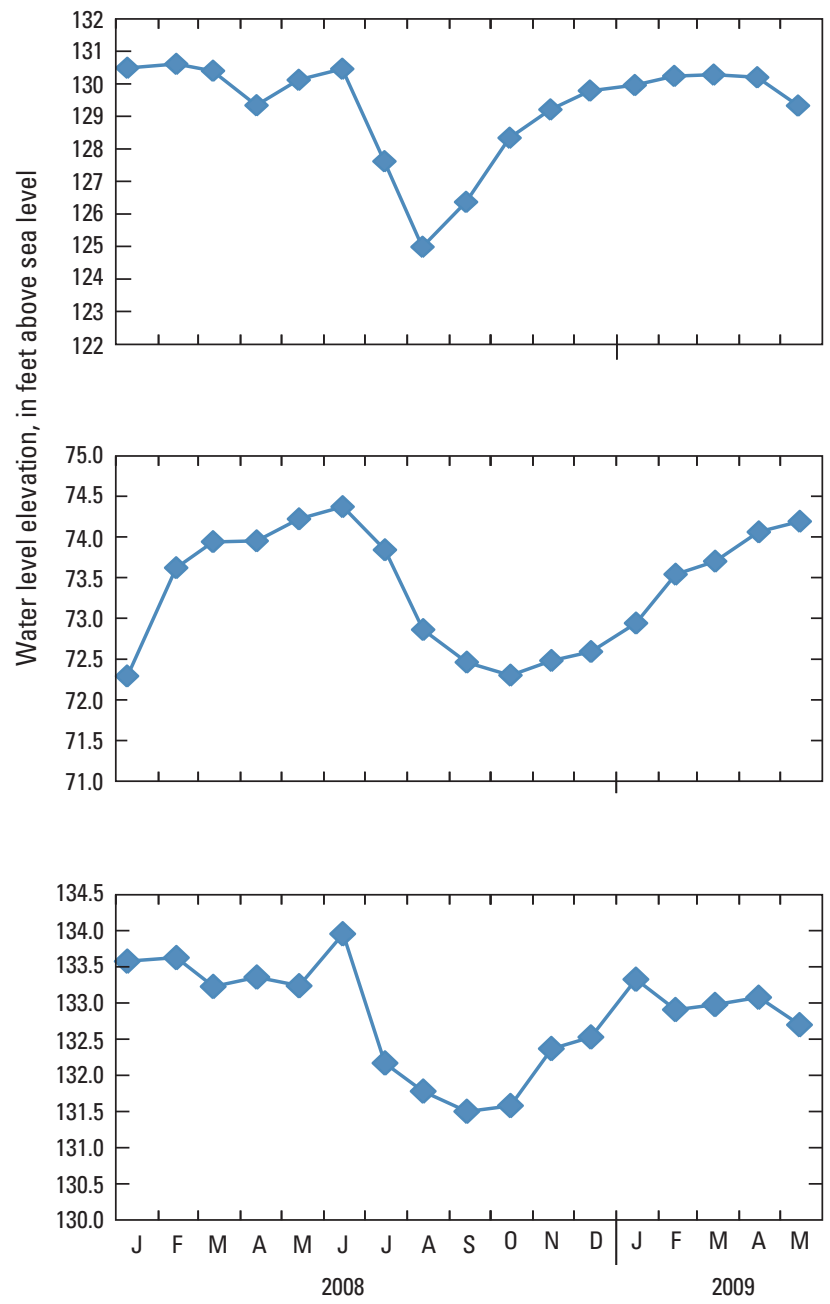

Figure 14.-Continued 


\section{Groundwater Budget}

Recharge from precipitation is the predominant inflow to the groundwater system for the study area, averaging about 15,600 acre-ft/yr from 1994-2009. Outflows from the groundwater system include discharge to streams, withdrawals for domestic use and agriculture, and submarine groundwater discharge to saltwater bodies (table 6).

Most of the readily measurable discharge from the groundwater system is discharge to streams as baseflow. Stream baseflow during 2003-09 averaged $6.36 \mathrm{ft}^{3} / \mathrm{s}$, or about 4,600 acre-ft/yr. Groundwater is the sole source of domestic use, both indoor and outdoor. Jefferson County PUD \#1 provides most of the water for domestic use, averaging around 833 acre-ft/yr (fig. 15). Of this, 90 percent of indoor usage is considered to recharge the groundwater system by way of septic systems, and 10 percent of outdoor use is considered to recharge the groundwater systems, resulting in around 70 percent, or about 592 acre-ft of discharge per year returning to the groundwater system. The remaining domestic water use is self-supplied, which amounts to just under 200 acre-ft, of which 136 acre-ft, amounting to about 70 percent of withdrawals, is returned to the groundwater system. Agricultural water use was estimated at 250,800,000 gal (about 770 acre-ft) per growing season of (May-September), and 10 percent of that is considered to recharge to the groundwater system.

Of the total 16,400 acre-ft of recharge to the system (natural recharge plus return flows), baseflow (4,600 acre-ft), public-water supply (833 acre-ft), self-supplied water (200 acre-ft), and agricultural water use (770 acre-ft), account for 6,400 acre-ft. The remainder of the recharge, 10,000 acre-ft, is assumed to be unmeasurable submarine groundwater discharge to surrounding saltwater bodies.
Table 6. Total estimable groundwater inflows and outflows, and residual, for the Chimacum Creek basin, Washington.

\begin{tabular}{lr}
\hline \multicolumn{2}{c}{ Recharge (acre-feet) } \\
\hline From precipitation & 15,600 \\
From public supply return flows & 592 \\
From self-supplied return flows & 136 \\
From irrigated agricultural return flows & 77 \\
Total inflow to groundwater system & 16,400 \\
\hline \multicolumn{2}{c}{ Discharge (acre-feet) } \\
\hline Discharge to baseflow \\
Discharge to Public Supply \\
Discharge to self-supplied domestic use \\
Discharge to agricultural use \\
Total estimable outflow from groundwater system \\
Residual (unobservable subaqueous outflow) \\
\hline
\end{tabular}

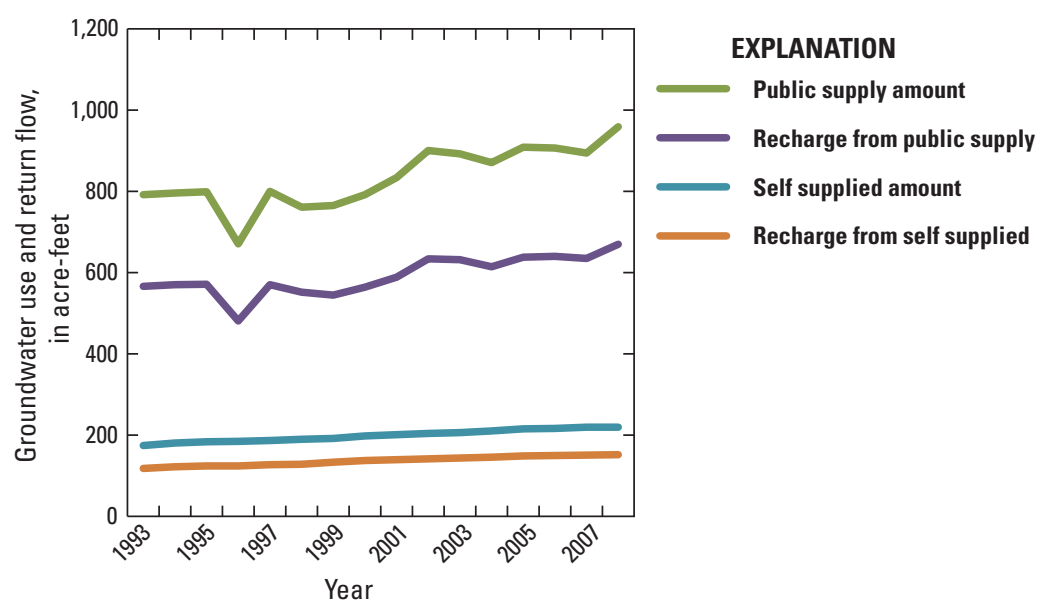

Figure 15. Publicly- and self-supplied water for domestic use, and associated return flows for the Chimacum Creek basin and vicinity, Washington. 


\section{Summary}

Growth of a population that depends exclusively on groundwater for water supplies, and widespread concerns about adequate baseflow for fish listed in accordance with the Endangered Species Act of 1973, has led to a need for better understanding of the groundwater system in northeast Jefferson County and its interaction with Chimacum Creek. This report presents characterizes the hydrogeology, natural recharge, water use and associated return flows, general groundwater flow patterns, and water budget, that can support further studies of the groundwater system and baseflows in Chimacum Creek.

The geologic setting is a north-deepening bedrock trough filled with unconsolidated glacial and interglacial deposits. To further understand the groundwater system, the study examined well logs describing these glacial outwash (advance and recessional), deposits and till, lacustrine, and alluvial deposits were studied with emphasis on lithology rather than on geologic history. The resulting maps of thickness and of the extent of hydrogeologic units, describe the following five characteristically different aquifer and confining units (excluding bedrock, for which only the top elevation was evaluated).

1. Upper Confining unit (UC).- - This unit is primarily alluvial deposits, along with other sources of fine-grained material that have low conductivity, and is about 2-50 feet thick.

2. Upper Aquifer (UA).- - This unit primarily is recessional outwash and coarser-grained till of moderate conductivity; and is about 2-70 feet thick.

3. Middle Confining unit (MC).- - This unit primarily is till with some fine-grained strata of the adjacent outwash layers. It has low conductivity and averages 50 feet in thickness, although in places it may reach more than 350 feet in thickness.

4. Lower Aquifer (LA).- - This unit is the primary water-bearing unit in the groundwater system. It is primarily advance outwash, but it includes coarser parts of other geologic units with which it is in contact. It has the highest conductivity of the five hydrogeologic units, and it averages 63 feet in thickness, although in places it exceeds 300 feet.

5. Lower Confining unit (LC). - This unit is poorly defined because its conductivity generally is low and it lies beneath a productive aquifer. Few well logs exist to characterize it. Consequently, it essentially encapsulates "all other glacial and interglacial deposits" and is highly variable in conductivity from place to place and with depth, but it largely reflects the poor conductivities of thick interglacial clays, till, and other typically poorly sorted glacial deposits.
The primary source of water to the groundwater system is recharge from precipitation. An annual average recharge during 1994-2009 of 15,600 acre-ft was estimated using precipitation-recharge relations developed for the region by Bidlake and Payne (2001) in conjunction with land cover information.

Another source of recharge is return flow from domestic and agricultural uses. This flow was estimated using Jefferson County records, population estimates, and per capita use rates, agricultural use estimates, and consumptive use estimates of 10 percent for domestic indoor use and 90 percent for outdoor and agricultural uses. Average annual groundwater recharge from this return flow during 1994-2009 is estimated to be about 600 acre-feet from public supply, about 140 acrefeet from self-supplied use, and about 80 acre-feet from agriculture.

Simonds and others (2004) used 110 wells to estimate the groundwater table elevations and flow directions, however there were large areas where there are not wells. The topography of the basin is such that the water table very probably reflects the surface topography, flowing generally toward Chimacum Creek and northward toward the mouth of the creek.

Synoptic streamflow measurements made in July 2007 generally were consistent with those made in 2002: steeper reaches in the headwaters underlain by bedrock were gaining; the middle reaches with very low slopes were losing, and the steeper and incised reaches approaching the mouth were gaining. A notable exception is the gage near the mouth (at CS14, which showed a marked difference with the 2002 measurements, with the comparatively highly sloped and incised reach losing. This is a subject for further investigation.

Measurements of monthly groundwater elevation were made during January 2008-May 2009 at the same locations that Simonds and others (2004) studied. These measurements were consistent with the monitoring during 2002-03, typically showing clear seasonal trends. The exceptions are two wells near surface-water features that exhibit seasonal trends that may be fluctuations related to these nearby surface-water features and more notably, well 35J01 had water table elevations about 70 feet higher. In addition to the increase in elevation, the record shows a seasonal signal that was not evident in the 2002 record, which had a steady decline over the monitoring period.

Long term (1994-2009) average recharge from precipitation is 15,600 acre-feet per year, with an additional 592 acre-feet of return flow from domestic public supply, 136 acre-feet of return flow from self-supplied domestic use, and 77 acre-feet of return flow from agricultural use. Withdrawals were 833 acre-feet by the PUD and 136 by domestic wells, with an additional 770 acre-feet withdraw for agriculture. The remaining recharge went to baseflow in Chimacum Creek (about 4,600 acre-feet on average), or unobserved submarine discharge to the surrounding saltwater bodies (10,000 acre-feet). 


\section{Acknowledgments}

Thanks to Bill Graham, Resource Manager, Jefferson County PUD\#1 for collecting monthly water-level measurements;: to Tom Culhane, and Dave Nazy, Washington Department of Ecology, to Neil Harrington, Jefferson County Environmental Health Specialist, and to Tom McKenna, Hydrologic Technician, USGS for synoptic streamflow .

\section{Selected References}

Bidlake, W.R., and Payne, K.L., 2001, Estimating recharge to ground water from precipitation at Naval Submarine Base, Bangor and vicinity, Kitsap County, Washington: U.S. Geological Survey Water-Resources Investigations Report 01-4110, 33 p.

Daly, Christopher, Neilson, R.P., and Phillips, D.L., 1994, A statistical-topographic model for mapping climatological precipitation over mountainous terrain: Journal of Applied Meteorology, v. 33, no. 2, p. 140-158.

Drost, B.W., Ely, D.M., and Lum II, W.E., 1999, Conceptual model and numerical simulation of the ground-water-flow system in the unconsolidated sediments of Thurston County, Washington: U.S. Geological Survey Water-Resources Investigations Report 99-4165, 254 p. (Also available at http://pubs.usgs.gov/wri/wri994165.)

Drost, B.W., 2005, Quality-assurance plan for groundwater activities, U.S. Geological Survey, Washington Water Science Center: U.S. Geological Survey Open-File Report 05-1126, 27 p. (Also available at http://pubs.usgs.gov/ of/2005/1126/.)

Easterbrook, D.J., 1979, The last glaciation of northwest Washington, in Armentrout, J.M., and others, eds., Cenozoic paleogeography of the western United States, Pacific Coast Paleogeography Symposium, No. 3: Society of Economic Paleontologists and Mineralogists Symposium Volume, p. 177-189.

Golder Associates, 2008, Groundwater storage in the Chimacum Creek Basin; Draft Step Report: Screening of Prospective Sources and Recharge Sites. Prepared for Public Utility District \#1 of Jefferson County, Washington and the Water Resources Inventory Area 17 Planning Unit, March 17, 2008.

Golder Associates, 2010, Water Demand and Availability Assessment for WRIA 17 - Stage 1. Prepared for the Water Resources Inventory Area (WRIA) 17 Planning Unit, June 2010
Grimstad, Peder, and Carson, R.J., 1981, Geology and groundwater resources of eastern Jefferson County, Washington: Washington State Department of Ecology Water Supply Bulletin no. 54, 125 p.

Hutchinson, M.F., 1989, A new method for gridding elevation and streamline data with automatic removal of pits: Journal of Hydrology, v. 106, p. 211-232.

Jones, M.A., 1996, Thickness of unconsolidated deposits in the Puget Sound lowland, Washington and British Columbia: U.S. Geological Survey Water-Resources Investigations Report 94-4133, 1 plate, scale 1:500,000.

National Oceanic and Atmospheric Administration, 2006, Endangered Species Act Status of West Coast Salmon and Steelhead, updated June 6, 2006, accessed July 28, 2011, at http://www.nwr.noaa.gov/ESA-Salmon-Listings/SalmonPopulations/Index.cfm.

National Land Cover Database, 2001: accessed May 2009, at http://www.mrlc.gov/multizone download.php?zone=1.

National Oceanic and Atmospheric Administration, 2007, Climatological data, Annual Summary, Washington: Asheville, N.C., National Climatic Data Center, v. 111, no. 13,30 p.

Oregon State University, 2009, PRISM Products: accessed May 2009, at http://www.prism.oregonstate.edu.

Pacific Groundwater Group, 2005, Hydrogeologic evaluation of Four Corners Well \#1: Prepared for Jefferson County Public Utility District \#1, May 18, 2005.

Parametrix, Inc., Pacific Groundwater Group, Inc., Montgomery Water Group, Inc., and Caldwell and Associates, 2000, Stage 1 Technical Assessment as of February 2000 - Water Resource Inventory Area (WRIA) 17, accessed July 28, 2011, at http://wria17.co.jefferson. wa.us/stage 1 assessment final.doc.

Rantz, S.E., and others, 1982, Measurement of stage and discharge, v. 1: U.S. Geological Survey Water-Supply Paper 2175, 284 p.

Ritter, D.F., 1978, Process geomorphology: Dubuque, Iowa, William C. Brown CompanyPublishers, p. 414.

Simonds, F.W., Longpré, C.I., and Justin, G.B., 2004, Groundwater system in the Chimacum Creek Basin and surface-water/groundwater interaction in Chimacum and Tarboo Creeks and the Big and Little Quilcene Rivers, Eastern Jefferson County, Washington: U.S. Geological Survey Scientific Investigations Report 2004-5058, 49 p. 
Tabor, R.W., and Cady, W.M., 1978, Geologic map of the Olympic Peninsula, Washington: U.S. Geological Survey Miscellaneous Investigation Series Map I-994, scale 1:125,000.

vanHeeswijk, Marijke, and Smith, D.T., 2002, Simulation of the groundwater flow system at Naval Submarine Base Bangor and vicinity, Kitsap County, Washington: U.S. Geological Survey Water-Resources Investigations Report 02-4261, 142 p. (Also available at http://pubs.er.usgs.gov/ usgspubs/wri/wri024261/.)
Washington State Department of Ecology, 2009, Final Cost Benefit, Maximum Net Benefit, and Least Burdensome Analyses, Chapter 173-517 Washington Administrative Code Water Resources Program for the Quilcene-Snow Watershed, Water Resources Inventory Area (WRIA) 17. Publication No. 09-11-029, November 2009.

Washington State Department of Health, Office of Drinking Water, 2011, Water System Data, accessed February 2011 at http://www.doh.wa.gov/ehp/dw/. 
Publishing support provided by the U.S. Geological Survey

Publishing Network, Tacoma Publishing Service Center

For more information concerning the research in this report, contact the Director, Washington Water Science Center

U.S. Geological Survey

934 Broadway, Suite 300

Tacoma, Washington 98402

http://wa.water.usgs.gov 
